\title{
Colaboração premiada, paternalismo processual e "juízes camaleões": simplificação e eficiência do procedimento na luta contra a corrupção
}

\author{
Awarded cooperation agreement, procedural paternalism and \\ "chameleon judges": simplification and efficiency of procedure in the \\ fight against corruption
}

Paulo Roberto Fonseca Barbosa ${ }^{1}$

Universidade de Lisboa, Lisboa, Portugal prfbarbosa@yahoo.com.br

http://lattes.cnpq.br/0904525886926574

https://orcid.org/0000-0002-9808-709X

\begin{abstract}
Resumo: Detectando-se uma espécie de paternalismo processual na atuação dos juízes, busca-se demonstrar que a dupla análise judicial do acordo de colaboração premiada, conforme previsto pela Lei $12.850 / 2013$, é ponto de desestabilização do sistema de justiça penal negociada brasileiro, contribuindo negativamente para uma série de inconsistências processuais, notadamente por transgredir os princípios constitucionais da imparcialidade e do juiz natural, sendo gênese de nulidades processuais. Nesse contexto, pretende-se responder ao seguinte problema: a simplificação do procedimento, envolvendo a confecção do acordo de colaboração premiada, com a extinção da dupla análise judicial do referenciado acordo, contribuiria para poten-
\end{abstract}

1 Doutorando em Ciências Criminais pela Universidade de Lisboa (2018). Possui graduação pela Universidade Estadual de Santa Cruz (2004). Atualmente é Juiz de Direito do Tribunal de Justiça do Estado de Sergipe (TJ/SE), Titular da Comarca de Canindé de São Francisco, tendo ingressado na carreira em janeiro de 2005. É também Juiz Eleitoral do Tribunal Regional Eleitoral do Estado de Sergipe (TRE/SE), titular da $28^{\mathrm{a}}$ Zona Eleitoral. Especialista em Ciências Criminais pela Faculdade Social da Bahia (FSBA) (2013). Mestre em Constitucionalização do Direito, com ênfase na área de Direito Penal, pela Universidade Federal de Sergipe (UFS) (2015). 
cializar o combate à corrupção sem afetar garantias fundamentais dos acusados? Para resposta do problema, utiliza-se da análise de jurisprudência e doutrina sobre a temática, incluindo estudo comparatístico entre institutos jurídicos estrangeiros congêneres.

Palavras-chave: Justiça penal negociada; Poder Judiciário; Paternalismo processual penal; Colaboração premiada; Direito comparatístico.

ABSTRACT: Detecting a kind of procedural paternalism in the performance of judges, it is sought to demonstrate that the double judicial analysis of the awarded cooperation agreement, as provided for by Law $12.850 / 2013$, is a point of destabilization of the Brazilian negotiated criminal justice system, contributing negatively to a series of procedural inconsistencies, notably for transgressing the constitutional principles of impartiality and the natural judge, being the genesis of procedural nullity. In this context, it is intended to answer the following problem: would the simplification of the procedure, involving the drafting of the awarded cooperation agreement, with the extinction of the double judicial analysis of the referenced agreement, contribute to enhancing the fight against corruption without affecting the fundamental guarantees of the accused? In response to the problem, we use the analysis of case law and legal theory on the subject, including a comparative study between similar foreign legal institutes.

KeYwords: Criminal justice negotiated; Judicial Power; Criminal procedural paternalism; Awarded cooperation agreements; Comparative law.

SUMÁRIO: Introdução; 1 Paternalismo judicial no acordo de colaboração premiada; 2 Quem disse que o juiz não participa do acordo de colaboração? 3 Contaminação judicial e (in)suportabilidade sistêmica: um réquiem ao duplo exame judicial do acordo de colaboração premiada à luz do direito comparatístico; Conclusões; Referências.

\section{INTRODUÇÃO}

A Lei n. ${ }^{\circ}$ 12.850/2013 inovou no cenário jurídico brasileiro ao permitir a existência de um acordo formal prévio entre as autoridades de persecução penal e o investigado com o intuito de estipular obrigações recíprocas, as quais, uma vez cumpridas, podem finalizar o processo 
criminal. Todavia, o legislador condicionou a validade do pacto a uma dupla verificação do Poder Judiciário, criando uma espécie de paternalismo judicial dentro de um almejado sistema consensual adversarial, onde o protagonismo das partes deveria ganhar substancial relevo. Isso vem causando incompatibilidades sistêmicas e materializando nulidades, dificultando, por efeito direto, o combate efetivo da corrupção. Nos trâmites da lei, ocorre mais ou menos o seguinte: o órgão investigador ou o acusador público relativiza a obrigatoriedade da ação penal em troca da confissão do colaborador e de sua renúncia a algumas garantias constitucionais, cedendo ainda eventual parte de sua liberdade e do seu patrimônio, além de contribuir de maneira imprescindível para a revelação eficaz de outros ilícitos penais encobertos pela capa protetora das organizações criminosas.

Notoriamente, essa evidente barganha, sintetizada pelo acordo de colaboração premiada, finca raízes num sistema processual adversarial e tem gerado problemas ao ser transplantada para o sistema processual brasileiro, o qual ainda procura o legítimo caminho acusatório traçado pelo legislador constitucional. Um desses problemas reside em estabelecer qual a verdadeira posição do juiz brasileiro ante um contexto desenhado sob o véu consensual da colaboração - continuaria ele atuando em atenção ao seu background processual inquisitorial (rectius, misto) ou, mudando de papel, vestiria a toga do juiz adversarial? Ou, num terceiro plano, estaríamos diante de um juiz híbrido, que deveria ser versátil para atuar, a depender das circunstâncias, como se fosse um verdadeiro camaleão, adaptando-se às cores de cada sistema processual? Em resposta, percebe-se o surgimento de um tertius genus, que é o juiz denominado metaforicamente de "juiz camaleão", marcado por fortes características de ambos os sistemas, resultado de um paternalismo judicial exacerbado e inserto num curioso modelo de "justiça negociada adversarial à brasileira" ainda em construção.

Na sequência, enfrenta-se o problema principal: a simplificação do procedimento, envolvendo a confecção do acordo de colaboração premiada, com a extinção da dupla análise judicial do referenciado acordo, contribuiria para potencializar o combate à corrupção sem afetar garantias fundamentais dos acusados? Responde-se positivamente. Mirando-se na experiência estrangeira e delimitando-se a participação judicial nos acordos 
de colaboração premiada a um único ato, propõe-se o fim da dupla análise judicial do acordo. Por fim, conclui-se que o Poder Judiciário, embora de maneira limitada, deve continuar como regente e detentor da última palavra do processo penal negocial, racionalizando essa incipiente forma de justiça, no afã de conter utilitarismos arbitrários.

\section{Paternalismo judicial no acordo de colaboração premiada}

Como muito vem sendo dito por ampla doutrina, o processo de "americanização" ${ }^{2}$ da justiça penal, desencadeado pelo transplante ${ }^{3}$ de fórmulas oriundas do sistema adversarial (adversarial system) ${ }^{4}$, de

2 Concordando com o termo, Langer (2004, p. 26-29). Em sentido contrário, Brandão (2015, p. 162).

3 Para escorar nossas ideias, utilizaremos as metáforas do "transplante" e da "tradução" na troca de institutos jurídicos entre sistemas processuais ante a ampla notoriedade científica de tais categorias doutrinárias. O termo transplante tem origem em Watson (1993, p. 21), quando argumenta com exemplos históricos que o direito não pode ser usado como uma ferramenta para entender a sociedade sem uma consideração cuidadosa dos transplantes jurídicos como elemento central, conceituando o transplante como: “[...] a mudança de uma regra ou sistema jurídico de um país para outro, de um povo para outro". Por sua vez, Langer (2004, p. 29-35) critica o pensamento de Watson ao perceber que a ideia de transplante seria muito rígida e não teria aptidão para captar as sutilezas de um mundo em constante transformação. Por isso, propõe o modelo da tradução jurídica, que seria mais adequando diante da expansão do pensamento jurídico causada pela globalização. Segundo Zilli (2019a, p. 19): "Enquanto os transplantes carregam a ideia de replicagem, as traduções ligam-se à noção de adaptação".

4 Ao longo do presente estudo, vamos nos referir ao sistema adversarial sempre como aquele proveniente do Common Law, eis que já consolidado nos E.U.A. Todavia, parte da doutrina sustenta a equivalência dos termos "adversarial” e "acusatório", conforme Langer (2004, p. 18-19), sendo esse o caminho aqui adotado. Justificamos nossa escolha por motivos didáticos e porque a colaboração premiada teve grande inspiração no acordo de cooperação americano (cooperation agreement), embora o resultado seja um sistema híbrido, com traços bem marcantes dos dois troncos processuais mais conhecidos, consoante veremos a seguir. Ademais disso, essa divisão vem perdendo importância, pois até mesmo a divisão mais tradicional (inquisitorial-accusatorial) vem ficando para história. Segundo Ambos (2003, p. 3-4): "In sum, the inquisitorial-accusatorial divide has only, if at all, a meaning in historic, pre-revolutionary terms.” Nessa ordem de evolução, outras divisões têm 
matriz anglo-saxã, para sistemas pretensamente acusatórios ou mistos (inquisitorial system) ${ }^{5}{ }^{6}{ }^{6}$, gestados na Europa Continental e América Latina, tem ensejado grandes dificuldades práticas ante incompatibilidades sistêmicas, produzindo nulidades. Dentre razões de ordem econômicas, sociais e políticas, ainda temos que sopesar o desconforto gerado entre os atores processuais por conta do movimento legislativo inovador ${ }^{7}$. Inicialmente, pode não haver por parte de alguns grande aceitação em relativizar princípios basilares e em reposicionar a atuação de figuras relevantes no sistema de justiça penal tradicional, sendo até normal que se busque a manutenção do status quo, rejeitando-se a vontade do legislador, mormente pelo viés interpretativo ${ }^{8}$. Por isso, é importante definir papeis, deixando bem clara missão atribuída a cada ator processual, com indicação precisa de limites e possibilidades, embora dita tarefa legislativa nunca seja alcançada - o que é perdoável, restando no mais das vezes amplo espaço de densificação prática para doutrina e jurisprudência.

No caso brasileiro, esse quadro da perda e ganho de poderes não atendeu parte da lógica consensual adversarial, implicando em confusão. Embora tenha atribuído grande autonomia às partes, e até a quem não é parte (vide o delegado de polícia), demonstrou grande carência do manto protetivo judicial em momentos, aos nossos olhos, desnecessários, fruto de uma cultura processual inquisitiva e ainda arraigada na credibilidade da

surgido, valendo conferir os modelos de hierarquia e coordenação projetados por Damaska (1986) em sua festejada obra: The faces of justice and state authority, notadamente páginas 16-46.

5 Mendes (2018a, p. 13) utiliza o termo "moderno sistema inquisitorial".

6 Mendes (2018b, p. 33) fala em extinção dos modelos puramente inquisitoriais "sem deixar rastro".

7 Contudo, tal inovação vem atender ao desenvolvimento social e as novas formas de criminalidade. Segundo Durkheim (1967, p. 90-95), o crime é algo normal e necessário ao desenvolvimento da moral e do direito e o criminoso um agente regulador da vida social. Os altos índices de criminalidade é que caracterizam o estado de anormalidade. Nesse ponto, o referido estado de anormalidade deve ser captado pelo legislador, criando leis adequadas para solucionar o problema social.

8 Langer (2004, p. 14) exemplifica com a reação dos juízes de um sistema inquisitorial ao perder poderes de investigação. Foi exatamente o que aconteceu na implementação do giusto processo italiano, na luta contra a máfia e corrupção generalizada, vide Panzavolta (2005, p. 602) e Orlandi (2016, p. 384-385). 
benção dos juízes. Explicaremos essa carência judicial sob a ótica do paternalismo ${ }^{9}$. Como cediço, o legislador, ao arquitetar o regime de colaboração premiada, deixou espaços para questionamentos da atuação judicial, mais precisamente a partir do primeiro momento no qual o juiz realiza o escrutínio do acordo de colaboração, debruçando-se sobre a regularidade, a legalidade, voluntariedade e a adequação do pacto, para fins de eventual homologação $0^{10}$.

Especificamente no que diz respeito a tormentosa atividade de adequação do acordo, embora a recente Lei n. ${ }^{\circ}$ 13.964/2019, tentando prestigiar a imparcialidade judicial, impeça o juiz de exercer sponte propria aquela atividade diante do caso concreto e nas hipóteses de ausência de homologação imediata, determinando agora a devolução do projeto de acordo às partes, de modo que procedam aos ajustes necessários ${ }^{11}$, ainda assim o juiz continua com a possibilidade de redirecionar os rumos do pacto. Sob tal perspectiva da atividade de adequação, o futuro tem tudo para ser um prolongamento problemático do passado, principalmente quanto ao postulado do juiz objetivamente neutro e da vedação legal de participação judicial nos acordos ( $\S 6^{\circ}$, do art. $4^{\circ}$, ainda intacto), colocados em risco permanente ante a permissão de "análise fundamentada do mérito da denúncia" ${ }^{12}$ e a possibilidade de o acordo ser "precedido de instrução" no momento da homologação ${ }^{13}$.

9 No presente estudo, consideraremos legítimo o paternalismo materializado em medidas adotadas com intuito de proteger determinados direitos e garantias fundamentais, independentemente da vontade de seus respectivos titulares, atrelado ao conceito de estado de vulnerabilidade. Sem vulnerabilidade, não pode haver paternalismo. Essa concepção é encontrada em Feinberg (1986, p. 5-8), quando explica a dicotomia entre espécies de paternalismo: i) paternalismo presumivelmente reprovável é aquele em que a proteção se dirige apenas ao indivíduo beneficiado (paternalismo benevolente) ou se dirige também a terceiros (paternalismo não benevolente); e ii) paternalismo presumivelmente não reprovável é o que se destina a proteger indivíduos em estado de vulnerabilidade, independentemente de consentimento.

10 Vide nova redação do $\S 7^{\circ}$, do art. $4^{\circ}$, da Lei n. ${ }^{\circ} 12.850 / 2013$, modificado pela Lei 13.964/2019.

11 Vide nova redação do $\S 8^{\circ}$, do art. $4^{\circ}$, da Lei n. ${ }^{\circ} 12.850 / 2013$, modificado pela Lei 13.964/2019.

12 Vide redação do novo $\S 7^{\circ}-\mathrm{A}$, do art. $4^{\circ}$, da Lei n. ${ }^{\circ} 12.850 / 2013$, incluído pela Lei 13.964/2019.

13 Vide redação do novo $\S 4^{\circ}$, do art. $3^{\circ}$-B, da Lei n. ${ }^{\circ} 12.850 / 2013$, incluído pela Lei 13.964/2019. Ao que parece, o legislador brasileiro abriu os olhos para a 
Com efeito, a previsão legislativa originária foi inovadora ao estabelecer, no mínimo, dois momentos de contato do juiz com o acordo de colaboração (homologação e sentença), exigindo já na fase homologatória a chancela definitiva e, por isso, vinculativa de algumas cláusulas que demandariam nítida atividade judicial cognitiva exauriente ${ }^{14}$. É esse duplo contato judicial, por imposição legal, com provas, meios de prova e agora até instrução prévia, que coloca o juiz numa delicada situação, obrigando-o a manter-se neutro em situações de indesejável, porém necessário, aprofundamento ao thema decidendum, sob pena de homologar em definitivo fatos incongruentes quando cotejados com uma base fáti$\mathrm{ca}^{15}$ (factual basis) ainda inexistente ${ }^{16}$. Tal quadro tem se agravado pela

angustiante situação do juiz no momento de realizar a análise do acordo de colaboração e para toda problemática que pode decorrer de um ato homologatório sem base fática robusta - esse seria o maior motivo para permitir a realização de instrução prévia, tal como já se aplica em âmbito internacional (art. 65, (3), (a) do Estatuto de Roma). Contudo, essa tentativa de esboçar um novo modelo de supervisão judicial do acordo de colaboração, mirando o processo penal internacional, pode ser a "cara" do qual problemas decorrentes da mescla dos sistemas processuais seja a "coroa", conforme detalharemos ao longo desse estudo. Nesse sentido, conferir Damaska (2010, p. 105), mormente quanto ao valor ambivalente da confissão "[...] created by blending Anglo-American and Continental European forms of criminal justice". Por sua vez, Schabas (2018, p. 292) reforça: "In the drafting of the Rome Statute, there were difficulties in circumscribing the rules applicable to guilty pleas of differing philosophical approaches to the matter in the main judicial system of national law".

14 Utilizaremos ao longo do trabalho a classificação proposta por Watanabe, em sua obra sobre a Cognição Judicial (2005, p. 127 e ss.). Assim, a cognição pode ser vertical em sua profundidade e horizontal em sua amplitude. No plano vertical, a cognição ainda pode ser exauriente e sumária. Por sua vez, na ótica horizontal, a cognição pode ser ilimitada ou limitada quanto ao objeto do conhecimento. As referenciadas classificações tandem a demonstrar o nível de vinculação do juiz ao thema decidendum, o que pode ensejar contaminação e quebra da imparcialidade.

15 Turner (2006, p. 514-515) adverte sobre a importância de escrutinar a base fática, embora as partes tenham adotado a premissa de revelar o mínimo possível da realidade factual nos acordos com a finalidade de que o juiz não interfira. Isso leva a que o juiz apenas tenha uma visão superficial do ocorrido e raramente rejeite o acordo. A autora ainda constata que essa passividade judicial tem conduzido os acusados a aceitarem crimes sem amparo legal (v.g. tentativa de homicídio culposo) ou crimes que não praticaram.

16 Badaró (2017, p. 143) demonstra preocupação com a neutralidade judicial ao levantar questionamentos sobre um visível acúmulo de funções pelo 
desmedida e notória criatividade do Ministério Público ao costurar os acordos com estipulação de cláusulas sem amparo legal e sem precisar objetivamente o catálogo de crimes a ser abarcado pela decisão judicial homologatória. Tudo isso cria um cenário e insegurança jurídica, prejudicando o combate à corrupção. Mas não é só isso.

A lógica do consenso adversarial confere autonomia ao Ministério Público para, conforme aspectos de conveniência e oportunidade ${ }^{17}$, mormente diante do desenvolvimento da investigação ou mesmo já com processo em tramitação, postular o perdão judicial para o colaborador, sendo essa possibilidade ainda presente no $\S 2^{\circ}$, do art. $4^{\circ}$ da Lei $n .^{\circ}$ 12.850/2013. O referido dispositivo, entretanto, possibilita ao juiz a aplicação do art. 28 do CPP brasileiro ${ }^{18}$, caso não concorde com o pleito ministerial, materializando nítido exercício de fiscalização do princípio da obrigatoriedade da ação penal ao juiz de um pretenso sistema de raiz adversarial ${ }^{19}$. Isso demonstra um significativo traço da atividade

Ministério Público, o qual estaria investigando, abraçando a verdade dos fatos por si escolhida e ainda desenhando a futura sentença penal, tudo validado por simples decisão homologatória. Poderíamos aqui vislumbrar que o autor faz uma crítica a atuação passiva dos juízes. Tal fato difere do nosso objeto de estudo, que se refere aos comandos legislativos de atuação dos juízes como atos estruturais do regime de colaboração.

17 O Min. Dias Toffoli indica no HC $127.483 /$ PR, de sua própria relatoria, j. em 27.08.2015, Tribunal Pleno, publicado em 04.02.2016, que a lei de colaboração premiada "[...] é expressa ao fixar a fase de homologação como o momento de sindicabilidade das cláusulas negociais, do ponto de vista de sua regularidade formal e legalidade, não de sua conveniência e oportunidade". Porém, veremos que não tem sido assim na prática.

O referenciado artigo foi modificado pela Lei 13.964/2019, a qual alterou o rito de arquivamento do inquérito policial e elementos de informação, afastando corretamente, aos nossos olhos, a supervisão judicial. Tal mudança, uma vez efetivada, irá conferir maior harmonia ao sistema, delimitando papéis, conforme agora propomos. Entretanto, o Min. Luiz Fux, no bojo da ADI 6.299 MC/DF, amparado em "impactos sistêmicos e financeiros", suspendeu: "[...] ad cautelam a eficácia do artigo 28, caput, do Código de Processo Penal, na redação dada pela Lei n. 13.964/2019. Nos termos do artigo 11, §2o, da Lei n. 9.868/1999, a redação revogada do artigo 28 do Código de Processo Penal permanece em vigor enquanto perdurar esta medida cautelar.” Esperamos que a vontade do legislador concretize-se logo.

19 Imperioso notar que esse tipo controle judicial sobre o pedido de perdão judicial será extinto com a vigência da nova redação do art. 28 do CPP. Desse 
de controle judicial, eis que o oferecimento de perdão ao colaborador, dentro de um panorama de justiça penal negociada, deveria constituir-se em elemento de barganha contido no espaço de consenso aberto entre acusação e defesa, sem ingerências. Dito diferente: as partes tudo podem dentro e nos limites do espaço reservado por lei.

Se é permitido ao juiz invadir aquele espaço, notamos algumas importantes consequências, a saber: i) a lógica do sistema negocial é quebrada; ii) a verdade exige mais provas; iii) as confissões demandam mais base fática; e iv) e o juiz passa a gerir a prova. Teríamos traços inquisitoriais enxertados no bojo da negociação penal, embora a lei exclua o juiz de participar do acordo. A partir daí, vislumbramos o distanciamento das tentativas em comparar o regime da colaboração ao sistema de barganha adversarial. Pensamos, ao que parece, que tem ocorrido uma verdadeira tradução (rectius, adaptação) de instrumentos negociais importados do sistema justiça criminal norte-americano, e também italiano, incorporados ao ordenamento brasileiro, gerando uma mescla de características propulsora de um sistema processual e personagens híbridos ${ }^{20}$, consoante veremos nas próximas páginas.

Outro ponto importante e já discutido no Supremo Tribunal Federal é referente a participação ativa dos delegados (federal ou estadual) na confecção dos acordos de colaboração, quando os fatos ainda

modo, caso o juiz não concorde com o perdão judicial, a irresignação do Ministério Público deverá ser materializada em forma de recurso. Sem previsão legal de recurso em sentido estrito e tratando-se de uma decisão interlocutória, que certamente tocará ao mérito da lide, o recurso que se nos apresenta adequado é a apelação residual. Ressaltamos, porém, que o tema é controvertido. Conferir, a propósito, Vasconcellos, (2018, p. 213-214).

O fenômeno da "hibridização" entre os sistemas acusatórios e inquisitoriais é tratado por Delmas-Marty (2008, p. 253 e ss.). Por sua vez, Schünemann (2013a, p. 307) lembra que o valor da confissão na Alemanha, no cotejo com o princípio da verdade material, também gerou o fenômeno da hibridização entre tais categorias processuais, pois a confissão teria valor de convencimento para acordos penais, mas não teria o mesmo valor em caso de instrução probatória, criando uma natureza variável para o conceito de verdade. Damaska (1986, p. 4-6) já há algum tempo detectava o fenômeno da hibridização quando anunciava que:"[...] adversarial traits can be identified in continental Europe and can even be quite conspicuous in some branches of the administration of justice, while inquisitorial features, sometimes quite conspicuous, can be found in Anglo-American lands". 
estejam na fase de investigação ${ }^{21}$. Tal desejo legislativo revela marcas inquisitórias inconciliáveis com órbita negociada, pois empurra o juiz para o âmbito prematuro e inquisitorial das investigações e, pior, com a possibilidade de homologar acordo de colaboração sem a anuência do titular da ação penal ${ }^{22}$. Contraditoriamente, o princípio da obrigatoriedade da ação penal é exigido no já referido $\$ 2^{\circ}$, do art. $4^{\circ}$ da Lei n. ${ }^{\circ}$ $12.850 / 2013$, ao passo em que é relativizado para viabilizar o acordo com os delegados, num provável caso de aliança política, resultante da força da bancada legislativa federal brasileira formada por policiais, em detrimento de princípios constitucionais e em benefício de uma política criminal utilitarista de emergência, a qual trará nódoas no combate do crime organizado e da corrupção.

Os pontos ora destacados não têm o condão de negar aqui a importância prática do paternalismo legislativo, o qual se mostra de grande importância em outros setores jurídicos. Muito menos se pretende afastar o acordo de colaboração do controle judicial. Objetivamos, sim, racionalizar o referido controle, harmonizando-o com princípios irrenunciáveis de um sistema maior (constitucional) e limitando-o no ambiente de negociação penal. A racionalização, por conseguinte, perpassa pela detecção e compressão de um nítido paternalismo processual, inserto no âmbito negocial da Lei n. ${ }^{\circ}$ 12.850/2013. Veremos que quanto maior for a compressão desse paternalismo, maior será a natureza adversarial ou acusatória do sistema, facilitando e purificando a atuação dos atores processuais, além de aumentar a segurança jurídica e a imparcialidade judicial, impedindo atuações políticas dos juízes. Isso porque a justiça

21 Esta é mais uma peculiaridade do sistema de "justiça negociada adversarial à brasileira”, a qual foi endossada pelo STF no julgamento da ADI 5508/ DF, Ação Direta de Inconstitucionalidade, Rel. Min. Marco Aurélio, j. em 04.12.2017, publicado em 11.12.2017. Prevaleceu o argumento de autoridade do STF, com o qual não concordamos, uma vez ferir a lógica acusatória desenhada na Constituição.

22 Uma das notas mais clássicas dos processos acusatórios é impedir aquele que participou das investigações de julgar o investigado. Entretanto, a lei sub examine possibilita que o juiz homologue o acordo entre delegado e colaborador, ainda na fase inquisitiva, e, mais para frente, já no âmbito processual, sentencie aquele mesmo colaborador. Tal situação não ocorre nos ordenamentos da Itália e U.S.A., como será demonstrado oportunamente. 
penal negociada se caracteriza pelo maior poder de disposição dos envolvidos (acusação e defesa), os quais protagonizam-se na construção de uma verdade consensual ${ }^{23}$. O juiz deve ser mero coadjuvante, sem exercício diretivo na construção do pacto. As partes, incluindo o juiz, devem, contudo, estar atentas aos limites (horizontal e vertical) de disposição contratual. Certamente, o princípio da legalidade ${ }^{24}$ é o norte a ser seguido, pois é atribuição do legislador acenar para as hipóteses passiveis de barganha ${ }^{25}$. É nesse ponto que o juiz deve atuar: impedindo ilegalidades.

Em se tratando de seara negocial, a atividade legislativa deve pautar-se no liberalismo constitucional, onde garantias sejam relativizadas voluntariamente, num verdadeiro processo de cooperação, calcado na equidade. Se o legislador retira do acusado (investigado ou mesmo condenado) a possibilidade de suspensão ${ }^{26}$ voluntária de suas próprias garantias, instaura uma situação de anacronismo ante o moderno Estado Democrático de Direito, ressoando aparente autoritarismo ${ }^{27}$. Visto por outro ângulo, o intento de proteção legislativa pode inclusive ter efeito reverso, prejudicando o acusado disposto a colaborar nos limites da lei, dificultando táticas defensivas. Se o leque de direitos materiais e processuais do colaborador, passíveis de barganha, é delimitado por lei e ainda

23 Badaró (2017, p. 139) explica que que a ideia de verdade consensual é ligada ao fenômeno de transformação do processo penal em instrumento principal de solução de conflitos, relegando a um plano inferior a verificação dos fatos. Segue o autor afirmando que, por essa ótica, até uma decisão firmada em premissas falsas pode ser aceitável.

24 Referimo-nos a legalidade em sentido amplo, incluindo a própria Constituição Federal.

25 Entretanto, a jurisprudência também exerce papel fundamental na densificação da atividade legislativa, sinalizando para hipóteses passíveis de suspensão e renúncias de garantias através de suas decisões. Para tanto, basta verificar as decisões do STF que são mencionadas nesse estudo. No âmbito internacional, chamamos atenção para as decisões emanadas da Corte Europeia de Direitos Humanos nos Casos Natsvlishvili e Togonidze $v$. Georgia. Application n. 9043/05, j. 08.09.2014, §88 e Scoppola v. Itália. Application n. 10249/2003, $\S 135$, dispensando interpretação ao art. 6 da Convenção Europeia dos Direitos do Homem, que garante o direito a um processo equitativo.

26 Não utilizamos o termo renúncia pois indicaria perda eterna de direitos, o que não pode ocorrer.

27 SANNA, Alessandra. Il "patteggiamento" tra prassi e novelle legislative: questioni nuove di procedura penale, Padova: CEDAM, 2018, p. 17. 
recebe o controle paternalista do juiz, seu poder de disposição é reduzido e, por conseguinte, seus benefícios serão menores. Assim, também serão menores as chances de desmontar organizações criminosas. No seio do processo penal negocial, o paternalismo do legislador só se mostrará legítimo quando objetive coibir colaborações que tenham como pano de fundo acordos embalados por situações manifestas de vulnerabilidade defensiva, que podem ser constatadas num duplo aspecto: deficiência substancial da defensa técnica ${ }^{28}$ ou violação ao desempenho da livre autodefesa.

Medidas paternalistas previstas em lei são proveitosas quando não descaracterizem a natureza do sistema processual penal negociado. Tais cautelas ostentam legitimidade ao criar mecanismos de controle judicial que não interfiram na liberdade contratual permitida por lei. Sob tal prisma, a previsão de um contrato escrito entre acusação e defesa com indicação de direitos e deveres colaterais é um instrumento de proteção cabível e louvável ${ }^{29}$. Ainda nesse quadrante, andou bem o legislador quando estabeleceu a obrigatoriedade da gravação das tratativas para eventual e posterior análise ${ }^{30}$, reforçando o adequado controle judicial e dando azo a formação de um objetivo sistema de nulidades processuais ${ }^{31}$. Em outros

28 Conferir súmula 523 do STF, regulando as hipóteses de nulidade por deficiência de defesa técnica. Outrossim, o novo artigo 3º-A, da Lei 13.964/2019 veio para dirimir dúvidas quanto a natureza da colaboração. A lei foi clara em dizer que o aludido acordo é "negócio jurídico processual e meio de obtenção de prova”. Em outras palavras: se analisado enquanto via para obtenção de benefícios para o colaborador, é meio de defesa; se visto enquanto instrumento de fortalecimento da acusação, é meio de prova. Denota-se, ainda, que, embora com essência processual, produz efeitos materiais, conforme preconiza Vasconcellos (2018, p. 61).

29 Outro razoável instrumento de proteção foi o "Termo de Confidencialidade", previsto pelo $\S 2^{\circ}$, do art. $3^{\circ}$-B, da Lei $13.964 / 2019$, tornando obrigatória uma prática já existente.

30 A inspiração do novo $\S 13^{\circ}$, do art. $4^{\circ}$, da Lei $13.964 / 2019$ parece ter sido italiana, ante o que preconiza o artigo 16-quarter, comma 3, do Decreto-legge 15 de gennaio 1991, n. 8, combinado com o artigo 141-bis do CPP. Ruga Riva (2002, p. 265) acena que tal medida visa evitar que a acusação exerça pressão sobre o acusado para obtenção de confissões ou mesmo colaborações sobre outros fatos, revestindo as declarações colhidas de parcialidade. Pelas mesmas razões, terá aplicação no contexto brasileiro.

31 O melhor caminho, ao nosso pensar, seria um sistema legal de nulidades processuais, sem prejuízo de que a jurisprudência solidifique outras hipóteses 
termos: a proteção do acusado colaborador pode ser implementada sem que para isso seja preciso desfigurar a linha adversarial do sistema, com indevidas e inoportunas incursões judiciais de jaez inquisitorial. A simplificação do rito e a delimitação de papéis potencializarão os resultados pretendidos pelo legislador de aniquilar células criminosas.

Deveras, são visíveis os benefícios sociais decorrentes da amplitude do campo negocial da Lei n. ${ }^{\circ} 12.850 / 2013$, reconhecendo e endossando práticas premiais anteriormente existentes no ordenamento jurídico brasileiro. Outrossim, não podemos deixar de relevar o grande mérito legislativo em ter disciplinando o rito da colaboração ${ }^{32}$, mormente pela inclusão de um acordo escrito. Por outro lado, o excesso de proteção, que termina por desfigurar o sistema, reside numa necessidade demasiada de impor o comando judicial de forma precoce, via decisão homologatória do acordo ou direção de nebulosa atividade de adequação (agora indireta) da avença, mesmo antes que acusação e defesa tenham cumprido todas as promessas pactuadas. Esse paternalismo judicial exagerado impede a formação de um sistema adversarial tradicional, criando em verdade um sistema brasileiro de barganha penal peculiar e diferente dos demais, marcado pela insegurança, imprevisão e instabilidade. O grande problema desse rito cheio de minucias e que exige do juiz um exercício de futurologia é que a complexa atividade de ajuste dos acordos seja colocada na cama de Procusto, com soluções carentes de constitucionalidade por ausência de razoabilidade.

Esse traço incongruente da atividade judicial no sistema de brasileiro, ao que parece, é único dentre os sistemas mais conhecidos. $\mathrm{O}$ legislador terminou criando uma zona cinzenta sobre a natureza do

não antevistas pelo legislador.

32 Romero (2017, p. 263) indica que a Lei 12.850/2013 é a única a prever um rito processual específico sobre a colaboração premiada, devendo ser interpretada sistematicamente e aplicada a outros delitos, em casos de lacunas legais, dada sua completude, reduzindo assim a discricionariedade e a arbitrariedade dos atores processuais sobre essa temática. Badaró (2015, p. 453) acena que a mens legislatoris em disciplinar o rito procedimental foi conter erros judiciários derivados de colaborações informais, donde não haveria justificativa em restringir dita garantia apenas ao crime organizado. Daí, também entende que, por analogia, a Lei n. $.^{\circ} 12.850 / 2013$ deve ser aplicada a todos os casos de colaboração premiada. 
sistema de justiça negociada, envolvendo dúvidas sobre importantes elementos processuais, quais sejam: verdade, confissão e gestão da prova. Pretendeu avançar ao sistema de base adversarial, mas conservou nuances inquisitoriais estruturais. Como visto, proibiu a atuação judicial nas negociações, mas exigiu do juiz ato prévio de homologação e ainda direção da atividade de adequação do acordo, controlando a formação das vontades, instaurando um estado de contradição sistêmica gerador de insegurança processual. Em outros sistemas, a função do juiz é bem definida, assim como também são nitidamente visíveis os papéis de acusação e defesa. Embora existam algumas exceções ${ }^{33}$, os atores processuais sabem quais são os seus pontos de partida e até onde podem chegar, seja por trilharem a vertente legislativa, ou mesmo por rejeitarem o texto de lei e adotarem como bússola as interpretações judiciais cristalizadas pela jurisprudência ${ }^{34}$. O certo é que um sistema de justiça pretensamente adversarial e pautado no consenso não se coaduna com um paternalismo judicial exagerado, sob pena de quebra da autonomia das partes, desencadeando outras consequências indesejáveis.

No contexto brasileiro, e ligando-se âmbito da colaboração premiada, resta saber o que se pretende sobre o papel do juiz: i) a participação na formação dos acordos, buscando uma verdade calçada em robusta evidência e gestão da prova, com relativização da confissão ${ }^{35}$;

33 Turner (2006, p. 503) noticia que os Estados americanos da Flórida e Connecticut's aceitam a participação judicial nos acordos (plea agreements), embora o direito processual penal norte-americano seja notoriamente conhecido por sua natureza adversarial. No primeiro, a participação é mais comedida, permitindo aos juízes o esclarecimento às partes sobre o que pode ser objeto do acordo. Quanto ao segundo, a ingerência judicial chega ao ponto de o juiz indicar qual acordo seria aceitável, inclusive tocando ao mérito do caso. Entretanto, o juiz que participar da elaboração do acordo não pode presidir eventual julgamento envolvendo o mesmo acusado.

Orlandi (2019, p. 14), prefere a lei à jurisprudência em matéria de colaboração premiada.

35 Essa parte inquisitorial ganha maior reforço agora diante da possibilidade - ao que parece - de o juiz determinar ex officio a instrução prévia antes de analisar a eventual homologação do acordo de colaboração. Essa "hibridização" de sistemas é prevista em tribunais penais internacionais, conforme já explicitado aqui. Contudo, referidas cortes tem o diferencial de suportar implicações de cunho histórico e político em suas decisões, razão por que a verdade 
ii) a ausência de participação na formação dos acordos, contentamento com a verdade consensual e ausência de iniciativa probatória; ou iii) a formação de um sistema hibrido, no qual elementos processuais possuem dupla face e a atuação judicial variará conforme o desenvolvimento do rito processual - ensejando a "justiça negociada adversarial à brasileira". Pelo caminhar da jurisprudência e à luz das modificações legislativas já efetivadas, a terceira via parece ter largado na frente, fragilizando o combate à corrupção. A seguir, analisaremos o que tem ocorrido na prática, o que esperar do futuro e como a lei pode ser ainda mais aperfeiçoada.

\section{QUEM DISSE QUE O JUIZ NÃO PARTICIPA DO ACORDO DE COLABORAÇÃO?}

A participação dos juízes nos acordos é algo permitido e negado ao mesmo tempo. É como se houvesse uma quebra momentânea do princípio da unidade do ilícito. Embora exista expressa proibição legal, a própria lei permite que os acordos de colaboração continuem sendo modulados por juízo de adequação judicial. O juiz poderia participar do acordo, mas sem olvidar a advertência: "se for participar, não exagere!"36. Eis aí o mote para o surgimento do nosso "juiz camaleão", que pode ser definido, ao menos nesse momento nacional de incertezas jurídicas, como a figura principal em definir o alcance dos elementos estruturais do sistema processual penal negocial e o raio de atuação de cada ator, adaptando-os e adaptando-se às cores do sistema escolhido ${ }^{37}$. Tudo vai girar em torno do grau de participação judicial. E para compreender

consensual, sem robusto substrato fático, não lhes seria suficiente no âmbito dos acordos penais. Sobre esse ponto específico, ver Damaska, (2010, p. 81).

36 Em forma de analogia, tomamos de empréstimo a ideia de Mendes (2000, p. 124) ao explicar a possibilidade permitida por lei de produzir poluição ambiental: "Se poluir, não exagere!".

37 Ao comentar a atuação dos juízes do ICC e ICTY, sublinhando a oscilação das regras na formação da prova, Ambos (2003, p. 32) traz subsídios para resolução do nosso problema, ao concluir que: "In sum, it is fair to say that the rules of evidence adopt, despite the broad powers of the Trial Chamber, a mixed approach combining civil and common law features. The practial application of these rules will ultimaly depend on the legal background of the judges who are given sufficient discretion to conduct trials in accordance with their own preferences". 
tal figura metafórica, analisaremos o papel do juiz ante três elementos processuais caros ao sistema de barganha penal brasileiro, que já foram aqui mencionamos, a saber: a verdade ${ }^{38}$, a confissão e a gestão da prova ${ }^{39}$.

A verdade no contexto da Lei n. ${ }^{0} 12.850 / 2013$ apresenta dupla face. É inquisitorial quando: i) exige duplo controle judicial do acordo; ii) possibilita ao juiz a fiscalização do princípio da obrigatoriedade da ação penal; iii) prevê que o acordo de colaboração entre delegado e investigado seja homologado judicialmente, prescindindo da anuência ministerial; iv) concorda que o juiz ex officio promova a oitiva processual do colaborador e aceite prévia instrução do acordo; e ainda v) impossibilita condenação do colaborador com base apenas na sua palavra. Tudo isso mostra características inquisitoriais da verdade. Em contrapartida, possui linhagem adversarial quando: i) possibilita a barganha entre acusação e defesa sobre quantidade da pena, progressão de regime de execução de pena "ainda que ausentes os requisitos objetivos"; ii) permite a aplicação de perdão judicial até mesmo postulado por delegado em fase prematura

38 Zilli (2019b, p. 98) rejeita o critério da verdade na distinção entre o sistema adversarial e inquisitorial, ao argumento de fragilidade do conceito de verdade como objetivo do processo e ainda diante do perigo de engrandecimento de tal meta. Segundo aquele autor, a única verdade possível seria a processual. Sempre pautado no respeito acadêmico, pensamos diferente. Independentemente dos adjetivos que complementem a verdade, ela é elemento chave na distinção entre sistemas processuais, justamente por delimitar a atuação dos atores processuais, conforme temos demonstrado ao longo do presente estudo. Na mesma direção, Ambos, (2003, p. 4).

Damaska (2003, p. 119-120) desenvolve interessante pensamento ao discorrer sobre o secular princípio do ônus da prova, o qual vai ter dimensionada sua importância a depender da disposição processual sobre quem terá a iniciativa de produzir prova dentro da relação penal. Nas palavras do autor: "Dove l'indagine sui fatti è principalmente compito del giudice, raramente tale onere grava exclusivamente sulle parti. La ripartizione degli oneri è evidente soprattutto nel processo penale, dove il giudice è tenuto (entro determinati limiti) a svolgere le proprie indagini indipendentemente dall'accusa e dalla difesa". Tal pensamento é justificativa para escolha do critério de gestão da prova como caminho a legitimar a atuação judicial. Em outra oportunidade (DAMASKA, 1997, p. 841), o mesmo autor trata das diferenças entre os processos anglo -americano (adversarial) e continental (inquisitorial), aduzindo que: "These differences reach the high point in criminal procedure: while the continental criminal judge takes the lion's share of factfinding activity, in Anglo-american lands procedural action is to a much greater extent in the hands of the lawyers for the prosecution and the defense". 
do processo; iii) aceita acordos de não persecução penal ${ }^{40}$, abortando a instrução probatória sob o crivo do devido processo legal; e ainda iv) endossa a suspensão das garantias processuais do acusado, notadamente o direito ao silêncio e a presunção de inocência, sobrevalorizando a confissão. Em tal perspectiva, a verdade é adversarial ${ }^{41}$.

A ausência de definição sobre a natureza da verdade irradia efeitos perturbadores sobre a confissão e tumultua a gestão da prova. Isso porque o valor da confissão e o poder de inciativa probatória do juiz dependerão justamente do conceito de verdade estabelecido pelo legislador ou pela jurisprudência. Se o processo somente contenta-se com a verdade de matriz inquisitorial, a confissão por si só não tem serventia para condenação, apesar de ser útil na formação do convencimento judicial, e o juiz pode alargar ex officio o campo probatório. Se a verdade adversarial já é suficiente, a confissão tem o poder de encerrar o processo e o juiz não tem disposição própria sobre a produção de $\operatorname{provas}^{42}$. Quando a natureza do sistema é bem definida, verdade, confissão e gestão da prova atuam em sintonia ${ }^{43}$. O contrário ocorre quando elementos dos sistemas se misturam na busca de uma tradução adequada, criando um tertius genus, um sistema híbrido ${ }^{44}$. O surgimento de um sistema processual penal negocial

40 Vide novo art. 28-A, do CPP e $\S 4^{\circ}$, do art. $4^{\circ}$, da Lei n. ${ }^{\circ} 12.850 / 2013$, conforme Lei n. ${ }^{\circ} 13.964 / 2019$.

41 Langer (2004, p. 10) evidencia que o conceito de verdade tem efeitos diversos em cada estrutura processual. Enquanto o conceito adversarial de verdade pode ser relativizado por acordos (plea agreements ou stipulations), o mesmo conceito ganha tons absolutos na seara inquisitorial e o juiz tem legitimidade para buscar a veracidade dos fatos perante um contexto de prova, não se contentando com acordos. Assim, entendemos que os conceitos de verdade consensual ou adversarial são sinônimos.

42 LANGER, Maximo. From legal transplants to legal translations: the globalization of plea bargaining and the Americanization thesis in criminal procedure. Havard International Law, [s. l.], v. 45, n. 1, winter, 2004. p. 1-64, p. 10-11.

43 Apesar das críticas envolvendo a passividade judicial norte-americana e o ativismo judicial alemão nos contextos de barganha penal, é imperioso admitir que a verdade, a confissão e a gestão da prova são elementos processuais bem definidos, o que termina por demonstrar certa previsibilidade e segurança.

44 Damaska (1997, p. 844-852) adverte que a mescla entre sistemas processuais oriunda dos transplantes pode ocasionar problemas, exemplificando com a indefinição sobre a colheita das provas nos tribunais. Para o referenciado autor, os transplantes devem ser bem estudados, mormente quanto aos aspectos 
híbrido, tal como albergado pela Lei n. ${ }^{\circ}$ 12.850/2013, traz consigo, quase que como um parto natural, o nascimento de um juiz adequado ao novo modelo, o qual deve ser capaz de traduzir a vontade legislativa em unir a essência dos sistemas adversarial e inquisitorial durante o percurso processual $^{45}$, com sabedoria ainda para materializar o paternalismo judicial permeado ao longo da citada lei em diferentes contextos, sem afetar os pilares de um incipiente devido processo penal negocial.

Com efeito, o paternalismo judicial apresenta-se num dos seus traços mais marcantes quando exige que o juiz exerça uma prévia sindicabilidade do acordo de colaboração premiada, para fins de homologação ${ }^{46}$. Parece-nos pairar uma presunção de vulnerabilidade permanente das partes. O legislador permitiu até a já questionada atividade diretiva de adequação do pacto, quando o juiz atuaria como uma espécie de moderador. Contudo, o juiz deve dirigir o acordo recatadamente, sem tocar ao thema decidendum, de modo que não esteja contaminado no momento da sentença ${ }^{47}$. Deve perscrutar o acordo com precisão cirúrgica ${ }^{48}$, sem

culturais do ordenamento receptor. Sobre a importância de entender os aspectos culturais em tal contexto, Chase (2005, p. 7) afirma que: "Not only is the invocation of 'culture' defensible as a tool for understanding dispute processes; it is also necessary. It fills gaps left open by other studies of the relationship between disputing and society".

45 Talvez aqui o salto legislativo encontre eco nas ideias de Langer (2004, p. 17) quando acena para a importância de considerar as diferenças e semelhanças entre tais sistemas, de modo a permitir a infiltração de ideias recíprocas, criando um quadro de evolução processual, mas sempre se atentando para as peculiaridades sociais, econômicas e políticas locais.

${ }^{46}$ Esse paternalismo poderia ter sido pior, eis que o projeto original (PL 150/2006) previa, no seu artigo $4^{\circ}$, a possibilidade de o acordo de colaboração ser feito por inciativa judicial ou requerimento das partes.

47 A doutrina é praticamente uníssona em dizer que o juiz deve fazer uma análise superficial, como se isso fosse tarefa fácil e sempre possível. Caso contrário, a nulidade é decretada, conforme decidiu o Ministro do STJ, Reynaldo Fonseca, no bojo do HC 354.800/AP, julgado em 19.09.2017. Aos nossos olhos, a construção de um modelo adequado de supervisão judicial dos acordos penais é um dos temas mais complexos da atualidade, demandando permanente estudo da comunidade jurídica nativa e internacional, tanto mais por conta do inacabado fenômeno de formação de sistemas híbridos.

48 Ruga Riva (2002, p. 453-457) compartilha da necessidade legislativa de definir as hipóteses premiais de forma mais objetiva (principio di precisione), reduzindo a utilização de termos que ensejam discricionariedade judicial 
cruzar o Rubicão, dentro de uma enorme sutileza processual e capacidade de profetizar a importância e a possibilidade empírica de verificação e refutação das cláusulas acordadas ${ }^{49}$, tanto mais porque a expectativa é que a decisão homologatória seja coberta pela imutabilidade, com pretensa força vinculante, que poderá ser obstada pelo novo $\S 2^{\circ}$, do art. $3^{\circ}-\mathrm{C}$, do CPP.

A partir já deste ponto, o juiz começa a ter a possibilidade de conferir a tônica que lhe aprouver ao processo, seja de cunho adversarial, seja de ordem inquisitorial, ante a abertura legal. É o seguinte: se homologa um determinado acordo sem grandes exigências materiais quanto ao manancial probatório que sustenta por exemplo um pedido de perdão judicial ou mesmo um acordo de não persecução penal, concorda com a verdade adversarial; se, em idêntica situação, deixa de homologar o acordo por entender que não existe lastro probatório nos autos de modo a formar seu convencimento, mesmo após instrução prévia, adota a verdade de cariz inquisitorial. As consequências processuais de cada escolha repercutem de forma substancialmente diversas na atuação das partes. Nessa toada, a análise de alguns julgados do STF tem demonstrado que os juízes modulam dos acordos ${ }^{50}$, tanto corrigindo ilegalidades quanto fazendo incursões (diretas e indiretas) sobre o mérito, sem, contudo, estabelecer um padrão de verdade $e^{51,52}$. O certo é que o sistema processual brasileiro não possui um modelo uniforme de supervisão judicial

49 Ferrajoli (2011, p. 8) explicita que a verificabilidade e a refutabilidade da acusação são condições exigidas pelo princípio da estrita jurisdicionariedade.

50 É bem verdade que não há iniciativa e nem presença dos juízes nas negociações, como ocorre na Alemanha e na Irlanda, sendo que nesse último país se fala até em plea bargaining judicial, inclusive com reuniões fechadas entre acusação e defesa nos gabinetes dos juízes. Nesse sentido, quanto ao direito alemão, conferir Weigend (2008, p. 45 e ss.) e Turner (2006, p. 516 e ss.), com relação ao sistema irlandês, ver O'Connor (2019, p. 5-7).

51 A participação judicial no acordo de colaboração, glosando cláusulas ou readequando sanções premiais, modificando a relação entre as partes, foi considerada pelo STF, no HC 127.483/PR, Rel Min. Dias Toffoli, julgado em 27.08.2015, Tribunal Pleno, publicado em 04.02.2016, como "elemento de existência” do próprio negócio jurídico processual.

52 Quanto maior o abuso (rectius, ativismo das partes) nas cláusulas, ensejando ilegalidades, maior a participação judicial, e maior ainda será a possibilidade de ocorrência de nulidade processual. 
do acordo de colaboração premiada, sem a identificação de um standard probatório mínimo para calçar as homologações.

Apesar de entender que a premissa do negócio adversarial deve ter como pano de fundo o protagonismo das partes, parte da doutrina ${ }^{53}$ tem sinalizado que, em culturas processuais calcadas no protagonismo judicial, como é o caso da brasileira, a redução dos espaços de disponibilidade pelo poder de controle das formas e do conteúdo dos acordos não seria inconciliável com o modelo de justiça negociada, concluindo, porém, não ser possível justapor o modelo brasileiro àqueloutro adversarial. $\mathrm{O}$ apego ao controle judicial se mostra até aceitável, porém, são grandes os riscos de que a adaptação ou mesmo tradução do sistema receptor gere um novo modelo ${ }^{54}$. Entendemos que esse novo modelo realmente vem sendo lapidado pela jurisprudência e os juízes têm se adaptado ${ }^{55}$ a esse novo paradigma $^{56}$, que traduz uma mescla de cores dos sistemas tradicionais, um mix processual. Essa adaptação judicial tem ensejado participação e direcionamento dos acordos e pode ser bem visualizada na Q.O. na Pet. 7074/DF, por meio de vários exemplos reais mencionados naquele acórdão,

53 ZILLI, Marcos. No acordo de colaboração entre gregos e troianos o cavalo é o prêmio. Boletim IBCCrim, São Paulo, ano 25, n. 300, p. 3-6, nov. 2017, p. 3.

54 Q.O. na Pet. 7.074/DF, Rel. Min. Edson Fachin, j. em 29.06.2017, Tribunal Pleno, publicado em 03.05.2018, quando defendeu a necessidade de adaptação do instrumento da colaboração ao ordenamento jurídico brasileiro, tecendo considerações sobre as diferenças substanciais entre os sistemas raiz romano-germânica e anglo-saxão.

56 Esse novo paradigma encontra eco na lição de Kuhn (1974, p. 84), quando constata que "And all crises close in one of three ways. Sometimes normal science ultimately proves able to handle the crisis-provoking problem despite the despair of those who have seen it as the end of an existing paradigm. On other occasions the problem resists even apparently radical new approaches. Then scientists may conclude that no solution will be forthcoming in the present state of their field. The problem is labelled and set aside for a future generation with more developed tools. Or, finally, the case that will most concern us here, a crisis may end with the emergence of a new candidate for paradigm and with the ensuing battle over its acceptance". O Min. Celso de Melo, decano do STF, em seu voto na Q. O. na Pet. 7.074/DF, Rel. Min. Edson Fachin, j. em 29.06.2017, Tribunal Pleno, publicado em 03.05.2018, também reconhece existência de "um novo paradigma de justiça criminal, em que o elemento preponderante passa a ser o consenso dos protagonistas do próprio litígio penal”. 
dentre os quais, citamos a rejeição e adequação das seguintes cláusulas: i) que previa possibilidade de pena máxima de vinte anos, mas só estipulava o regime prisional nos primeiros dois anos e dois meses, sem previsão de regressão; ii) que continha anuência do colaborador para acesso em contas bancárias e total movimentação financeira de terceiros; iii) que previa o direcionamento de $20 \%$ de tudo que fosse devolvido pelo colaborador para a Procuradoria da República em detrimento da Petrobrás, verdadeira vítima. Os exemplos listados denotam participação (rectius, paternalismo) judicial professoral ${ }^{57}$, a qual persistirá a teor do $\S 8$, do art. $4^{\circ}$ da Lei n. ${ }^{\circ} 12.850 / 2013$. Nesse ponto, não há grande aprofundamento ao mérito das investigações, apenas simples juízo de legalidade.

D'outra banda, e agora a situação muda, o nosso "juiz camaleão" tem que potencializar suas habilidades, pois são várias as hipóteses nas quais o exame do mérito (juízo de fato) se mostra necessário, sob pena de julgar realmente tal qual Themis - com os olhos vendados ${ }^{58}$. Com efeito, parte minoritária dos Ministros sustentou essa ideia com fortes argumentos ${ }^{59}$. O Min. Gilmar Mendes defendeu o exame da legalidade via análise vertical dos fatos como pressuposto da homologação, exemplificando com a impossibilidade de aplicação prematura de perdão judicial já na homologação do acordo, quando não se tem base fática sólida para afirmar se o colaborador é ou não líder da organização e, caso seja isento de processo, não será mais objeto de investigação $0^{60}$; 61 deixando entrever

57 O juiz atua como um professor, acenando para ilegalidades gritantes, quando não se constituem mesmo em inconstitucionalidades. Outros exemplos ilegais podem ser citados: i) cumprimento imediato de pena; ii) fixação de regime inexistente de cumprimento de pena; iii) compartilhamento de informações sigilosas de terceiros sem autorização judicial; iv) modificação de competência criminal etc.

58 O próprio legislador determina que o acordo de colaboração seja remetido ao juiz com "cópia da investigação" (vide nova redação do $\S 7$, do art. $4^{\circ}$ da Lei n. ${ }^{\circ}$ 12.850/2013, conforme Lei 13.964/2019). Não teria sentido mandar remeter os autos da investigação e impedir a leitura judicial, ainda mais agora com instrução prévia permitida pelo novo $§ 4$, do art. $3^{\circ}$-B da Lei n. ${ }^{0}$ 12.850/2013. O Min. Ricardo Lewandowiski trilhou essa mesma linha no julgamento citado. Conferir: STF, Q.O. na Pet. 7.074/DF, Relator: Min. Edson Fachin, j. em 29.06.2017, Tribunal Pleno, publicado em 03.05.2018.

61 Badaró (2017, p. 143) lembra dos colaboradores imunizados e daqueles que já aceitam penas mais brandas prematuramente, os quais passaram ao largo 
que encampa o conceito de verdade típico de sistemas inquisitivos. Por aí, comungando das razões de Sua Excelência, já se percebe que o "sistema adversarial à brasileira" comporta um conceito dúplice de verdade.

Outro exemplo tormentoso reside nos acordos patrimoniais, quando o colaborador renúncia parte de seu patrimônio, embora continue com outro montante menor. Sem adentrar ao mérito dos fatos (instrução), não há como o juiz descortinar se os bens negociados fazem parte ou não da empresa delitiva, sendo a legislação penal brasileira taxativa ao determinar a perda em favor da União do produto do crime ou de qualquer bem ou valor angariado pelo agente ${ }^{62}$. Noutro ponto, mas permanecendo ainda no âmbito patrimonial, face ao paternalismo judicial temporão contido na possibilidade de determinar a adequação do acordo ${ }^{63}$, caberia também questionamentos sobre a razoabilidade das disposições patrimoniais pelo viés da legalidade e, sem dúvidas, pelo filtro da constitucionalidade. Nesse contexto, tanto uma participação judicial intrusiva ${ }^{64}$ quanto a passividade judicial perante o acordo consistiriam em condutas permitidas pela Lei n. ${ }^{o} 12.850 / 2013$, tudo consequência de sua natureza híbrida.

Mais uma fonte de problema aparece quando o juiz analisa em conjunto as duas bandas do mérito (juízo de legalidade e juízo de fato), verificando se o caderno de investigações e sua base fática é congruente com o rosário de crimes inseridos no acordo. Isso ainda pode ser feito pois o juiz continua ${ }^{65}$ como fiscal do princípio da obrigatoriedade da

de um controle judicial mais aprofundado, a luz de uma verdade discricionária, caso homologado o acordo de colaboração.

62 Art. 91, inciso II, alínea "b", do CP brasileiro, quando trata dos efeitos da condenação.

${ }^{63}$ A lei fala em "adequação dos benefícios pactuados" e "adequação dos resultados" - puro juízo de razoabilidade, com ampla abertura, por isso, para atuação judicial, vide incisos II e III, do \$7, do art. $4^{\circ}$ da Lei n. ${ }^{\circ} 12.850 / 2013$, respectivamente. A propósito, o que seria uma cláusula inadequada?

${ }^{64}$ Diversamente da participação judicial professoral, a participação judicial intrusiva é incisiva, como o próprio nome indica, tocando ao mérito do processo, avaliando provas e impondo ingerências substanciais no acordo, tal como proposto nos votos já aqui mencionados e proferidos pelos Ministros Gilmar Mendes e Ricardo Lewandowiski.

65 Vide decisão liminar do STF, proferida pelo Min. Luiz Fux, já citada anteriormente. 
ação penal ( $\$ 2^{\circ}$, do art. $4^{\circ}$ da Lei n. $\left.{ }^{\circ} 12.850 / 2013\right)$. Não fosse assim, criaríamos uma alternância esquizofrênica ao tentar identificar quando deve ou não ser exercida a ação penal. Por certo, a todo o momento o juiz pode materializar o princípio da congruência ${ }^{66}$. Contudo, diante de um sistema híbrido, o conceito esperado de verdade processual e o peso da confissão fática do colaborador dependerá da matriz sistêmica judicialmente adotada. Certamente, seria indesejada ou mesmo perigosa a admissão judicial de uma verdade consensual, amparada numa confissão descolada de um mínimo probatório, embora isso se mostre possível.

É permitido, desse modo, ao juiz modular o acordo de colaboração, analisando verticalmente e horizontalmente questões legais e meritórias no momento homologatório anterior à sentença ${ }^{67}$. Se controla e modula o acordo, o juiz deve cerca-se de cuidados no ato homologatório. Isso porque a homologação implica em reconhecimento de que uma pretensão se encontra equivalente a um padrão predeterminado, como se o próprio pedido fosse julgado, sendo pressuposto para irradiação dos efeitos desejados e formação da coisa julgada material ${ }^{68}$. Disso resulta 0 perigo de homologar acordos de colaboração sem exame dos fatos, com base fática raquítica, dada a possibilidade de incongruências insanáveis ${ }^{69}$.

${ }^{66} \mathrm{Na}$ Itália, a obrigatoriedade da ação permite que o juiz adentre ao mérito, acenando ao Ministério Público a correção da tipificação dos fatos, na forma do art. 423, do CPP italiano, conforme explica Sanna (2018, p. 126-128). Ainda na Itália, exatamente sobre o papel do juiz no contexto da colaboração processual, Omodei (2019, p. 2) explica que: "Nell'analisi quindi delle ipotesi di collaborazione processuale in merito al delitto di associazione a delinquere di stampo mafioso, non si può non tenere in considerazione il vincolo che grava sull'accusa di portare avanti l'azione penale, vincolo per il cui controllo è costantemente preposto l'organo giudicante, vero dominus della vicenda". Isso se confirma pela nova redação do $\S 7^{\circ}-\mathrm{A}$, do art. $4^{\circ}$, da Lei n. ${ }^{\circ} 12.850 / 2013$, incluído pela Lei n. ${ }^{\circ}$ 13.964/2019. DIDIER JR., Fredie; BOMFIM, Daniela. Colaboração premiada (Lei n. 12.850/2013): natureza jurídica e controle da validade por demanda autônoma - um diálogo com o Direito Processual Civil. Civil Procedure Review, München, v. 7, n. 2, p.135-189, may.-aug., 2016, p. 155.

69 Em razão da verificação judicial do acordo de colaboração em dois tempos, Bottini (2017, p. 191) adverte acrescentando que, mesmo em caso de mudança de competência judicial em virtude de foro por prerrogativa de função ou desmembramento de fatos criminosos noticiados e já homologados, o novo juiz ou tribunal não deve alterar a o exame legal anteriormente realizado 
Muito embora o legislador tenha criado uma espécie ainda cinzenta de coisa julgada secundum eventum probationis ${ }^{70}$, imperioso notar que há abertura legal para hipóteses clausuladas que sairão da mira judicial, gerando intocabilidade dos colaboradores, que apenas terão que cumprir o que foi acordado em desfavor de terceiros, retirando ou reduzindo seu passado criminal do âmbito instrutório.

Portanto, percebemos que o posicionamento doutrinário e jurisprudencial, que sustenta um controle judicial superficial do acordo de colaboração, com o objetivo de preservar a imparcialidade judicial, não pode ser encarado com ar de naturalidade. Tudo perpassa pela maestria legislativa em equilibrar a segurança ao colaborador, sem quebrar a imparcialidade judicial. Se a boa intenção do legislador, ao exigir a dupla apreciação judicial do acordo, era garantir a segurança jurídica do colaborador, pensamos que essa invenção tem trazido mais problemas do que benefícios. Trata-se, nesse ponto, de inconciliável e extremo paternalismo judicial dentro de um sistema de justiça penal negociada, onde as partes devem assumir os ônus de suas condutas, sem prejuízo do controle judicial único da legalidade em momento oportuno. Como, então, alcançar o ponto de equilíbrio entre proteção ao colaborador e imparcialidade judicial?

\section{CONTAMINAÇÃO JUDICIAL E (IN)SUPORTABILIDADE SISTÊMICA: UM RÉQUIEM AO DUPLO EXAME JUDICIAL DO ACORDO DE COLABORAÇÃO PREMIADA À LUZ DO DIREITO COMPARATÍSTICO}

Dentro de um diferente sistema negociado em formação, que vem recebendo densificação jurisprudencial e novos aportes doutrinários, o juiz deve busca o seu papel tendo por norte o texto constitucional e, mais precisamente, o devido processo penal ${ }^{71}$, estruturado numa gama de prin-

sobre a base fática. Segundo o autor, isso garantiria segurança jurídica, sem afetar a independência dos juízes.

70 Didier JR e Bonfim, (2016, p. 167) constatam que o sistema processual penal recebe com desconforto esse novo regime de formação da coisa julgada, eis que as decisões homologatórias não possuem regulamentação legal específica em matéria de colaboração.

71 Algo semelhante ao giusto processo italiano, materializado pelo art. $111 \mathrm{da}$ Constituição daquele país. 
cípios relevantes. Dentre tais princípios, interessa-nos agora o postulado do juiz imparcial, arranhado pelos traços paternalistas e inquisitoriais do regime de colaboração. Ao que parece, as excessivas ingerências judiciais determinadas pelo legislador vêm causando mais problemas de ordem processual do que garantias aos colaboradores, pois são gênese de questionamentos sobre a imparcialidade judicial ${ }^{72}$. Ademais disso, ainda cabe mencionar outros problemas: i) conflitos de competência, os quais, por sua vez, podem resultar em agressão ao princípio constitucional do juiz natural; ii) conflitos de atribuição envolvendo também o princípio do promotor natural; e a iii) formação de uma perigosa verdade consensual entre juízos distintos.

Para escorar o quadro de contaminação judicial a ser esboçado, utilizaremos mutatis mutandis o estudo e os argumentos utilizados por Schünemann ${ }^{73}$, onde o autor trabalha de forma inédita o problema da (im)parcialidade judicial. Transportaremos parte da argumentação ali reproduzida para a arena processual penal negocial brasileira. De antemão, faremos desde já duas constatações metodológicas. A primeira, não utilizaremos o ordenamento processual penal brasileiro como base

72 Mendes (2018a, p. 18) defende que o acordo falhado deve ser retirado dos autos. Inclusive, já houve projeto de lei (PL 8.613/2017) cujo conteúdo era tornar impedido do juiz que homologar a colaboração premiada para processar e julgar a ação penal respectiva dada perda da imparcialidade. Sem explicitar razões, o projeto foi retirado de análise pelo próprio autor. Agora, com a inclusão do art. $3^{\circ}$-B, no CPP pela Lei 13.964/2019, prevendo o juiz das garantias, teremos uma pequena redução dos prejuízos processuais, eis que o inciso XVII atribui a tarefa de homologar o acordo de colaboração àquele juiz, o qual também ficaria impedido de proferir a futura sentença, resguardando o princípio da imparcialidade. Contudo, outros problemas virão, pois a própria lei referida diz que, recebida a denúncia, o juiz da instrução não se vincula às decisões do juiz das garantias $\left(\$ 2^{\circ}\right.$, do art. $3^{\circ}-\mathrm{C}$, do $\left.\mathrm{CPP}\right)$, incluindo fatalmente as decisões sobre o acordo de colaboração. Assim: quem seria o juiz responsável por homologar e julgar a colaboração feita após o recebimento da denúncia? O mesmo juiz da instrução? Ou o processo retornaria ao juiz das garantias para eventual homologação? Por hoje, o certo é que o polêmico juiz das garantais encontra-se suspenso, ante a decisão liminar proferida pelo Min. Luiz Fux, no bojo da ADI 6299 MC/DF, com futuro incerto.

73 SCHÜNEMANN, Bernd. O juiz como um terceiro manipulado no processo penal? Uma confirmação empírica dos efeitos perseverança e correspondência comportamental. In: GRECO, Luís. (coord.). Estudos de direito penal, direito processual penal e filosofia do direito. São Paulo: Marcial Pons, 2013b, p. 205-221. 
para interpretação sistêmica, pois ainda destila em si inquisitoriedade em vários aspectos, notadamente na possibilidade de iniciativa instrutória judicial e decretação de medidas cautelares ex officio ${ }^{74}$. Não fazendo essa exclusão, não haveria problema algum (como não tem havido) envolvendo o princípio da imparcialidade judicial. A segunda será de ordem delimitativa, pois o princípio da imparcialidade terá exame apenas no microssistema negocial da colaboração ${ }^{75}$. Daí por que já ficam excluídos argumentos retóricos que se refiram ao sistema processual matriz, tais como recebimento de denúncia e decretação de prisões cautelares como atos decisórios que "não" implicariam em parcialidade ${ }^{76}$.

Voltando ao estudo, Schünemann traça considerações sobre o sistema processual penal alemão, aduzindo que o juiz assume o domínio da ação penal logo após o oferecimento da denúncia pelo Ministério Público, tendo acesso direito a totalidade do inquérito policial. O mesmo juiz, se receber a denúncia, será o competente para instruir e julgar o feito. A partir daí, e levando em conta a natureza inquisitorial do processo penal alemão, Schünemann lança mão da teoria da dissonância cognitiva ${ }^{77}$ para demonstrar empiricamente a quebra da imparcialidade judicial. Por essa teoria, cada indivíduo tende a manter a harmonia das informações por si já incorporadas, rejeitando ideias contrárias àquelas já existentes. Para

74 Conferir Zilli (2019b, p. 101-102).

75 Mendonça (2017, p. 75) constata a existência de um microssistema brasileiro composto pelas demais leis que tratam de benefícios penais aos colaboradores e afirma que a Lei n. ${ }^{\circ}$ 12.850/2013 é a principal desse microssistema.

76 Em verdade, grande parte da problemática do sistema processual penal brasileiro nesse ponto se funda na prevenção como um dos critérios de fixação de competência jurisdicional. Enquanto parte dos países europeus evoluíram ao separar o juiz do julgamento dos elementos de investigação e mesmo da instrução processual, o sistema brasileiro permanece o mesmo de quase 80 anos atrás.

77 Conferir Festinger (1957, p. 2-3), quando, de arranque, indica a substituição das palavras "incoerência" e "coerência" por "dissonância" e "consonância", respectivamente, para, na sequência, explicar: "The basic hypotheses I wish to state are as follows: 1 . The existence of dissonance, being psychologically uncomfortable, will motivate the person to try to reduce the dissonance and achieve consonance. 2. When dissonance is present, in addition to trying to reduce it, the person will actively avoid situation and information which would likely increase the dissonance". 
isso, a teoria conta com o "efeito perseverança" e o "princípio da busca seletiva de informações", os quais tendem a confirmar hipótese anteriormente considerada verdadeira, superestimando informações favoráveis e subestimando tudo que lhe for contrário. Haveria uma busca de informações, mesmo inconscientemente, para confirmar a hipótese inicial.

O experimento foi promovido por meio de uma simulação computadorizada de uma audiência de instrução e julgamento, com base em fatos criminais verdadeiros, previstos no § 120 do Código Penal Alemão (libertação, indução ou auxílio à fuga de presos). O caso abertamente tinha base para condenação e absolvição. Foram utilizadas quatro hipóteses e duas variáveis ${ }^{78}$. As perguntas e repostas já estavam anteriormente preparadas e eram fornecidas no decorrer da audiência em tempo pelo computador, o qual era gerido pelo condutor da experiência. A base de dados era idêntica para todos os envolvidos, com o propósito de captar eventuais diferenças comportamentais apenas em razão da profissão dos envolvidos, a saber: 58 juízes criminais e membros do Ministério Público. A simulação, entretanto, teve a oralidade substituída pela forma escrita.

Sem maiores aprofundamentos na pesquisa, vamos direto ao ponto que hic et nunc nos interessa, ou seja, o resultado empírico quanto a primeira hipótese testada. De acordo com a pesquisa, todos os 17 juízes que tiveram conhecimento do inquérito condenaram. Por sua vez, houve equilíbrio entre os juízes que não foram municiados com aquele instrumento informativo, sendo 8 condenações e 10 absolvições. A primeira hipótese foi, portanto, confirmada: o conhecimento do inquérito, geralmente com inclinação incriminadora, conduz o juiz a condenar. O transporte desse resultado para o sistema negocial edificado pela Lei n. ${ }^{\circ} 12.850 / 2013$ nos

78 As hipóteses foram: 1) o juiz que possui conhecimento prévio do conteúdo do inquérito condena com mais frequência do que o juiz sem aquele conhecimento; 2) durante a audiência de instrução e julgamento, o juiz que conhece previamente o inquérito erra mais no armazenamento de informações do que o juiz sem aquele conhecimento; 3 ) os erros são reduzidos quando o juiz desconhece previamente o inquérito e o percentual da redução será maior se o juiz puder formular perguntas aos sujeitos de prova; e 4) o juiz faz mais perguntas aos sujeitos de prova durante a instrução quando tem conhecimento prévio do inquérito. As variáveis, independentes e alternáveis, foram: 1) conhecimento do inquérito; e a 2) possibilidade de formular perguntas durante a instrução processual. 
leva a concluir que há quebra de imparcialidade caso o juiz homologue o acordo de colaboração premiada e persista ele mesmo na prolação da correlata sentença. A conclusão merece explicação.

Se o juiz é, comprovadamente, como acabamos de ver, alvo do efeito perseverança e atua pautado no princípio da busca seletiva de informações apenas com o conhecimento do inquérito policial, muito mais influenciado será pela confissão do acusado e pelo exame direto dos elementos probatórios trazidos com acordo de colaboração. Imaginemos algumas situações possíveis: i) o juiz, de maneira fundamentada, rejeita o pedido de homologação do acordo, valorando a base fática existente; ii) o juiz homologa o pedido de acordo, que é cumprido, e sentencia o colaborador; iii) o juiz homologa o pedido de acordo, que é cumprido, e sentencia o delatado; iv) o juiz, em caso de descumprimento do acordo homologado, sentencia o ex-colaborador. Em tais hipóteses, o postulado do juiz imparcial é posto em xeque ${ }^{79}$.

Além de inquinar a imparcialidade judicial, o paternalismo em análise desencadeia outros pontos de tensão processual. A veia utilitarista que viaja pelo "sistema adversarial à brasileira", potencializada pelo vazio legislativo sobre definições específicas acerca da competência jurisdicional, tem gerado um quadro permanente de insegurança e materializado nulidades ${ }^{80}$. As regras têm sido construídas casuisticamente, desnudando maior imprestabilidade da decisão homologatória do acordo de colaboração antes da sentença. Imaginemos o que de ordinário acontece na fase embrionária da colaboração. O colaborador geralmente noticia a

79 Palomares (2009, p. 34) sinaliza a importância da aparência de imparcialidade, na linha dos julgamentos do TEDH, realçando que: “Tan trascendental resulta la exigencia de imparcialidad que incluso las apariencias pueden revestir importancia, pues afectan, como ya se ha dicho, a la confianza de la sociedad en la justicia y en concreto a la de las partes en el processo (Sentencias del TEDH, caso Piersack, de 1 de octubre de 1982, De Cubre, de 26 de octubre de 1984, o Hauschildt, de 24 de mayo de 1989)".

Badaró (2016, p. 171-204) retrata bem esse quadro de insegurança, envolvendo as lacunas da lei que têm possibilitado manipulação das regras de competência, ex post factum, com burla ao princípio do juiz natural, inclusive citando processos reais para conformação de suas assertivas. Ao final, arremata: "Diante de uma má legislação, a jurisprudência em geral, é vacilante e insegura. Não se pode extrair dos julgados, em especial dos tribunais superiores, critérios seguros de aplicação". 
existência de vários crimes, com vários personagens, sem preocupação com questões técnicas sobre competência jurisdicional ${ }^{81}$. O membro do Ministério Público ou o Delegado objetivam desmontar toda empresa delitiva. Em contrapartida, o colaborador busca sua liberdade. Porém, que fazer quando os crimes têm jurisdições territoriais distintas?

Nessa hipótese, a doutrina tem notado a necessidade de uma atuação conjunta entre membros do Ministério Público atuantes em diferentes jurisdições ${ }^{82}$. Os vários fatos delitivos seriam cindidos e tomariam a forma de "anexos". Parte dos anexos seria encaminhada para o respectivo juízo competente, o qual teria a possibilidade de homologar somente os fatos ocorridos em sua jurisdição. Outrossim, cada juízo apenas teria conhecimento dos fatos ocorridos em seu território. Ao final, teríamos um único acordo de colaboração sendo homologado (ou não) por vários juízos territorialmente distintos. Tal malabarismo jurídico ${ }^{83}$ torna-se frágil diante de uma única divergência judicial interpretativa no momento de cada uma das futuras sentenças, por exemplo. Outro entrave residiria no momento do juiz avaliar o cumprimento do acordo e sua eficácia sem conhecer a íntegra da trama delitiva ${ }^{84}$, o que seria essencial, por exemplo,

81 Esse problema, que envolvia a amplitude desmedida da colaboração, foi pensado pelo legislador reformador, a teor do novo $\$ 3^{\circ}$, do art. $3^{\circ}-\mathrm{C}$, da Lei n. ${ }^{\circ}$ 12.850/2013, incluído pela Lei n. ${ }^{\circ}$ 13.964/2019. Entretanto, tendo em mira regras de experiência pelas quais os colaboradores buscam resolver toda gama de ilícitos de sua vida pregressa num só acordo, antecipo duas possibilidades: i) redução dos acordos de colaboração, por desinteresse dos colaboradores; ou a ii) inobservância dessa regra pela prática dos atores processuais, com aval da jurisprudência.

VERÍSSIMO, Carla. Principais questões sobre competência para homologação do acordo de colaboração premiada. In: BOTTINI, Pierpaolo Cruz; MOURA, Maria Thereza de Assis (coord.). Colaboração premiada. São Paulo: Revista dos Tribunais, 2017, p. 122.

83 Contra improvisações jurídicas, são precisas as palavras de Canotilho e Brandão (2017, p. 149): "Esta garantia do juiz legal é imprescindível para a salvaguarda da confiança comunitária no sistema de justiça penal, defendendo-o de manipulações atrabiliárias na designação do juiz da causa que comprometem a isenção e imparcialidade que devem constituir a marca-de-água do múnus judicial e assim a própria realização da justiça do caso".

84 A própria Lei n. ${ }^{\circ} 12.850 / 2013$ determina no $\S 1^{\circ}$, do art. $4^{\circ}$, que: "Em qualquer caso, a concessão do benefício levará em conta a personalidade do colaborador, a natureza, as circunstâncias, a gravidade e a repercussão social 
na dosimetria da pena, já que os acordos geralmente trazem em si um espaço de fixação da pena em concreto. O novo $\$ 3^{\circ}$, do art. $3^{\circ}-\mathrm{C}$, da Lei n. ${ }^{\circ}$ 12.850/2013 vem como possível solução.

O STF também tem contribuído negativamente em matéria de competência, demonstrando desapego ao princípio do juiz natural, bem como ao princípio da independência funcional dos juízes. Isso porque, embora tenha firmado em mais de uma oportunidade ${ }^{85}$ que a colaboração premiada, de maneira isolada, não serve como instrumento de definição de competência, consolidou, na sequência, o entendimento pelo qual lhe cabe exercer sua prerrogativa exclusiva de deliberar, dentre os anexos do acordo de colaboração, quais devem permanecer sobre sua competência ${ }^{86}$, conferindo força vinculante aos acordos que homologar ${ }^{87}$. Melhor dizendo: caso o colaborador cite no acordo o envolvimento de uma única autoridade com foro por prerrogativa de função no STF, toda investigação deve ser encaminhada àquela Corte, inclusive os anexos que não mencionem dita autoridade. O STF, então, após homologar o acordo, que repercutirá em toda investigação, filtra e escolhe os crimes que serão por si julgados. $\mathrm{Na}$ prática, o STF tem homologado acordos sem ser o juiz natural da causa.

E o grande problema é que a homologação do acordo vai produzir efeitos vinculantes ao desempenho do verdadeiro juiz natural da causa que receber (de volta) os anexos rejeitados pelo STF e que deverá instruir e julgar o mérito da demanda ${ }^{88}$. Parte da doutrina entende que não há nada

do fato criminoso e a eficácia da colaboração". Sem que o juiz tenha conhecimento integral dos fatos que estruturam o acordo, o comando normativo em tela torna-se letra morta, sendo foco de potencial nulidade.

85 Ver Inq. 4428, Rel. Min. Edson Fachin, DJe 23.06.2017. Conferir, ainda, Inq 4.130 QO, Rel. Min. Dias Toffoli, DJe 3.2.2016 e HC n. ${ }^{\circ}$ 81.260/ES, Pleno, Relator Min. Sepúlveda Pertence, DJe 19.4.2002.

86 Ver Inq. 3515, Rel. Min. Marco Aurélio, Tribunal Pleno, DJe 14.03.2014.

87 É o que se depreende do dispositivo contido na decisão da Pet. 5244, Rel. Min. Teori Zavascki, j. em 19.12.2014, ora transcrita: "Ante o exposto, homologo o 'Termo de Colaboração Premiada'. De fls. 3-19, com a ressalva acima indicada, a fim de que produza seus jurídicos e legais efeitos perante qualquer juízo ou tribunal nacional, nos termos da Lei 12.850/2013”.

88 Por relevantes e oportunos, mais uma vez recorremos aos ensinamentos de Canotilho e Brandão (2017, p. 153): “Já não será assim, porém, se o STF não detiver competência para o processo em $1^{\mathrm{a}}$ instância de tal réu. Neste quadro, o juízo homologatório do STF figurará perante o juiz competente para a causa 
de ilegal nisso, uma vez que a decisão de homologação restaria preclusa e o juiz de instância inferior não teria legitimidade para modificar o que seria um ato jurídico perfeito ${ }^{89}$. Todavia, discordamos desse entendimento. Se o STF não tem competência originária para homologar o acordo com relação àqueles que não têm o chamado "foro privilegiado", o ato jamais poderá ser qualificado como "perfeito", ante patente agressão ao postulado do juiz natural. A inconstitucionalidade não pode ser convalidada pela preclusão assim de maneira tão gritante e utilitarista, simplesmente pelo argumento de autoridade.

Ante a necessidade de delimitação da pesquisa, existem ainda muitos outros problemas que não serão abordados aqui ${ }^{90}$. Mas o que já foi dito é suficiente para demonstrar que essas manobras jurídicas para definição de competência, além da atribuição de efeito vinculante a decisão homologatória, são decorrentes em grande medida da análise em dois momentos do acordo de colaboração. O vácuo temporal existente entre a homologação do acordo e a sentença fornece tempo para intensa movimentação dos atores processuais, sendo morada de boa parte das indagações relacionadas ao juiz natural e a imparcialidade do órgão julgador. Tudo isso ainda traz à reboque conflitos de atribuição envolvendo também o princípio do promotor natural e a própria atividades de investigação ministerial ${ }^{11}$, bem como contribui para formação de uma perigosa verdade consensual buscada a qualquer custo.

Entretanto, partindo para uma análise comparatística sobre colaboração premiada, encontramos algumas possíveis soluções para os problemas apontados. Dois dos países modelos na luta contra associações

como o juízo de uma qualquer outra corte de $1^{\mathrm{a}}$ instância, não podendo vincular, dada a independência recíproca que entre ambos intercede".

89 BOTTINI, Pierpaolo Cruz. A homologação e a sentença na colaboração premiada na ótica do STF. In: BOTTINI, Pierpaolo Cruz; MOURA, Maria Thereza de Assis (coord.). Colaboração premiada. São Paulo: Revista dos Tribunais, 2017, p. 185-200, p. 190-192.

90 Como problemas ligados à progressão de regime ante o juiz natural da execução penal, problemas referentes ao sobrestamento de inquéritos futuros em outros juízos etc.

91 É o que pode ser verificado no bojo da Pet 7065, Rel. Min. Edson Fachin, 2 Turma, j. 30.10.2018. 
criminosas e agentes públicos corruptos, Itália e Estados Unidos ${ }^{92}$, têm rica experiência a ser estuda na área da justiça penal negociada. A parte que interessa mais precisamente ao nosso estudo repousa em duas figuras: i) o verbale illustrativo dei contenuti della collaborazione; e ii) o cooperation agreements.

Na Itália, o legislador criou o verbale illustrativo dei contenuti della collaborazione, que alberga objetivos claros: i) garantir transparência no gerenciamento processual da colaboração; ii) estabelecer o momento e os limites do direito premial; iii) selecionar qualitativamente os colaboradores ${ }^{93}$. Ante um significativo histórico de declarações falsas $^{94}$, a credibilidade e a confiabilidade deveriam sempre figurar em primeiro plano ${ }^{95}$. Nesse contexto, o verbale pode ser conceituado como o instrumento escrito que possibilita o primeiro momento de controle da atividade colaborativa e, resumidamente, traça o espaço temporal e as diretrizes advindas do colaborador e que irão guiar a investigação criminal preliminar ${ }^{96}$. O seu conteúdo é previsto em lei ${ }^{97}$, tratando-se de evidente sinalagma entre o Estado e o colaborador, donde transparece a natureza contratual do verbale ${ }^{98}$.

92 Utilizamos essa ordem, pois foi nessa ordem que as grandes associações criminosas cresceram.

93 DE PASCALIS, Paola. Il problema della disciplina del verbale illustrativo in rapporto alla figura dei testimoni di giustizia (art. 16-quarter d.l. 15 gennaio 1991, n. 8). Riv. it. dir. e proc. pen., Milano, fasc. 4, p. 1263, 1-23, 2004, p. 2.

94 Orlandi (2019, p. 6-7) exemplifica com um dos famosos casos envolvendo falsas confissões e erro judiciário no processo penal sobre a morte de um magistrado, no ano de 1991, na cidade de Palermo.

95 O art. 106, comma 4 do CPP italiano é uma das medidas para obtenção de confiabilidade do depoimento.

96 Segundo Ruga Riva (2002, p. 264), il verbale é o verdadeiro coração da colaboração. De Pascalis (2004, p. 2, tradução nossa) sublinha o caráter preliminar e a forma resumida do verbale, conceituando-o como "[...] um documento programático que individualiza o perímetro da atividade declarativa que o colaborador prepara para formalizar em típicos atos de investigação preliminar, cristalizando o conteúdo da colaboração (ou do testemunho)".

97 Art. 16-quarter commi 1, 2, 4 e 5 da Lei n. 82/91.

98 Giordano (2001, p. 56). Divergindo sobre dita natureza contratual, ver Omodei (2019, p. 11). 
Outrossim, diferentemente do acordo de colaboração do sistema brasileiro, que pode ser acessado e estudado por simples pesquisa em sites de busca na rede mundial de computadores tão logo o sigilo processual é quebrado, o verbale illustrativo dei contenuti della collaborazione é ainda um "objeto misterioso" 99 e cercado de cautelas. Talvez por isso, a doutrina italiana venha divergindo sobre pontos relevantes de sua aplicação ${ }^{100}$, incluindo a sua própria natureza como de ato de investigação ${ }^{101}$, uma vez que a concessão das medidas de proteção ao colaborador perpassa obrigatoriamente pela análise de uma Comissão Central, regulada pelas normas do processo administrativo, formada por um Secretário de Estado (que preside a comissão), dois magistrados e mais cinco pessoas escolhidas dentre funcionários e oficiais com experiência em matéria de criminalidade organizada ${ }^{102}$. Todavia, ao nosso sentir, é evidente que o aspecto investigativo se sobrepõe ao administrativo.

Porém, o que diverge profundamente entre os sistemas italiano e brasileiro é o tratamento da imparcialidade judicial. Na Itália, qualquer decisão anterior que implique em mínima análise do mérito é motivo de quebra da imparcialidade judicial, causando impedimento para julgar o mesmo processo. Portanto, o verbale illustrativo sempre será um objeto desconhecido para o juiz que julgar o mérito do processo. A Corte Constitucional Italiana, desde o início do giusto processo, sempre foi bem sensível ao princípio da imparcialidade judicial, encarando-o como pedra de toque de todo sistema. Razão disso, as palavras do legislador constituinte reformador, que exigem um julgamento davanti a giudice terzo $e$

99 LAUDATI, A. La collaborazione con la giustizia ed il verbale illustrativo dei contenuti: Un "oggetto misterioso" introdotto dalla legge 45/2001. Diritto e giustizia, Milano, n. 10, p. 1-34, 2003, p. 34.

${ }^{100}$ Conferir, por exemplo, De Pascalis (2004, p. 3-4). Ver, ainda, Ruggiero (2010, p. 1-6) sobre a validade das declarações feitas além do prazo de 180 dias.

${ }^{101}$ Ruga Riva (2002, p. 263-264) extrai a natureza investigativa da nova redação do art. 12 comma 2 lett. b) do Decreto-legge 15 de gennaio 1991, $n$. 8. No mesmo norte, D’Ambrosio (2002, p. 127). Para Orlandi (2002, 172-173), o verbale illustrativo nasce como ato de natureza administrativa e somente toma a forma de ato de investigação penal com o acolhimento do colaborador ou testemunha pelo programa de proteção.

${ }^{102}$ Conforme art. 10 do Decreto-legge 15 de gennaio 1991, n. 8. 
imparziale (art. 111, da Constituição italiana), vêm sendo reforçadas ano a ano por várias decisões ${ }^{103}$.

Embora criticado, não se pode negar a importância prática do verbale illustrativo ante as estatísticas ${ }^{104}$. Suas semelhanças no cotejo com o acordo de colaboração brasileiro ressoam nítidas, desde o prazo para cumprimento do acordo até as finalidades legislativas intrínsecas em combater o crime organizado e a corrupção a partir de suas entranhas. Dada as similitudes, o exame comparatístico possibilita a extração e o consequente transplante daquilo que potencialmente pode servir de mecanismo de aperfeiçoamento do sistema de barganha penal no Brasil. Dois pontos chamam atenção: i) o juiz prolator da sentença só conhecerá o verbale illustrativo dei contenuti della collaborazione na fase de julgamento (dibattimento) ${ }^{105}$, não podendo, em nenhum momento, adequar o acordo escrito elaborado entre o Ministério Público e defesa - cada parte assume o ônus de suas ações e omissões; e ii) o verbale illustrativo dei contenuti della collaborazione poderá ser firmado entre o investigado e o chefe de polícia, mas desde que obtenha parecer favorável do Ministério Público, ou seja, a

103 Conferir: Sent. 26 de outubro de 1990, n. 496; Sent. 12 de novembro de 1991, n. 401; Sent. 30 de dezembro de 1991, n. 502; Sent. 25 de março de 1992, n. 124; Sent. 22 de abril de 1992, n. 186; Sent. 26 de outubro de 1992, n. 399; Sent. 16 de dezembro de 1993, n. 439; Sent. 15 de setembro de 1995, n. 432; Sent. 24 de abril de 1996, n. 131; Sent. 6 de julho de 2001, n. 224; Sent. 5 de dezembro de 2008, n. 400; Sent. 3 de julho de 2013, n. 183. Na doutrina, Tonini (2018, p. 627) confirma a impossibilidade de um mesmo juiz participar de fases distintas do processo depois de proferir atos decisórios, sob pena de quebra da imparcialidade.

${ }^{104}$ Orlandi (2019, p. 12) informa que no primeiro semestre de 2016 cerca de 1.300 colaboradores estavam submetidos no programa especial de proteção, o que inclui cerca de mais 4.700 familiares ou parentes mais próximos, totalizando 6.000 pessoas em situação de proteção estatal.

105 A lei prevê uma hipótese excepcional de a colaboração ter início no curso do dibattimento, mesmo sem o verbale illustrativo (Art. 16-quinquies, comma 3, do Decreto-legge 15 de gennaio 1991, n. 8). Nesse caso, o juiz deve conceder prazo de lei para redação do verballe illustrativo, podendo reconhecer, no momento oportuno, as atenuantes legais. Contudo, pela sistemática italiana referente ao princípio da imparcialidade, o juiz que tiver acesso prévio ao verbale illustrativo não deve julgar o mérito do respectivo processo. No mesmo tom, conferir Ruga Riva (2002, p. 268-269). 
titularidade da ação penal e a possibilidade de colaboração não saem do domínio ministerial ${ }^{106}$.

Por sua vez, no sistema americano, o ponto de comparação reside nos cooperation agreements ${ }^{107}$, que se constituem em importantes instrumentos de investigação policial, sendo exemplo prático do famigerado "dilema do prisioneiro". Isso porque o colaborador, geralmente ator coadjuvante de uma organização criminosa, aceita delatar às autoridades toda a trama criminosa, incluindo conhecimentos específicos que dificilmente seriam obtidos, em troca de benefícios penais, tendo contra si o medo de que outros comparsas delatem primeiro e obtenham melhores benefícios ${ }^{108}$. O objetivo aqui não é obtenção de culpa do investigado, embora a confissão seja essencial. O alvo maior é identificar fortes indícios que permitam o desenvolvimento das investigações para desnudar os mais altos escalões das organizações criminosas, sendo comum a afirmação pelo qual "se usa o peixe pequeno para apanhar o peixe grande"109. Do sistema adversarial americano, podemos extrair também dois pontos interessantes no confronto com a colaboração premiada brasileira e italiana, quais sejam: i) a presença de um acordo escrito ${ }^{110}$ que somente é valorado judicialmente no momento da sentença; e ii)

106 Ver: Art. 11, comma 3, do Decreto-legge 15 de gennaio 1991, n. 8.

107 Para Roth (2016, p. 754), é o documento que estabelece os termos do acordo entre promotor e delator.

${ }^{108}$ A inspiração normativa repousa nas Convenções de Palermo e de Mérida (Article 26 of the United Nation's Convention Against Transnational Organized Crime - UNTOC e article 37 of the United Nations Convention Against Corruption).

109 STRANG, Robert R. Plea bargaining, cooperation agreements, and immunity orders. In: INTERNATIONAL TRANING COURSE VISITINGS EXPERT'S PAPERS, 155., 2015, Japão. Anais [...]. Japão: UNAFEI, 2014. p. 30-37. (Resource material series, n. 92), p. 32.

${ }^{110} \mathrm{O}$ acordo escrito deve conter basicamente os crimes confessados pelo colaborador e a especificação do tipo de apoio às investigações sobre outros crimes praticados por terceiros, além da promessa do promotor público de submeter ao tribunal o pedido de reconhecimento da atividade colaborativa e seus respectivos benefícios acordados. Segundo Roth (2016, p. 753-754), essa prática de documentar as negociações tem se tornando mais comum recentemente, notadamente no U. S. Departamento of Justice. As razões propulsoras dessa necessidade de documentar as tratativas são duas: i) aumentar as garantias do colaborador, facilitando a captação do seu apoio; e ii) possibilitar a utilização 
as autoridades de investigação dependem da aprovação do promotor público para formalizar acordos de cooperação ${ }^{111}$.

Nesse aspecto, o desenvolvimento do estudo comparatístico e pontual entre os referidos sistemas de barganha penal mostra-se bastante promissor na busca por respostas ao nosso problema, sem olvidar o estudo empírico realizado por Schünemann. Constatamos assim que o sistema negocial brasileiro é o único dos três que: i) determina a dupla e prematura análise judicial do acordo de colaboração; ii) possibilita que o acordo seja "adequado" pelo juiz, implicando em participação, ao menos indireta, na construção do ato; iii) autoriza que um mesmo juiz rejeite, adeque ou homologue um acordo e ainda assim sentencie o colaborador; e, por fim, iv) permite que a atuação do Ministério Público seja rebaixada ao desejo da autoridade policial, ao possibilitar que o juiz homologue acordos dirigidos pela polícia sem anuência daquele órgão ministerial. Tais problemas são fruto da dupla análise judicial do acordo de colaboração premiada, figura legal que merece ser melhor ponderada pela comunidade jurídica brasileira.

\section{Conclusões}

Nossas conclusões sustentam as hipóteses iniciais, quais sejam: i) o paternalismo judicial exagerado, materializado pela dupla análise judicial do acordo de colaboração premiada, prejudica a construção do paradigma ideal de justiça negociada, eis que exige atuação judicial prematura, reduzindo o protagonismo das partes contratantes; ii) a dupla análise judicial do acordo de colaboração premiada relativiza o princípio da imparcialidade, conforme estudo empírico de Schünemann, e viola o princípio do juiz natural, ante manobras processuais noticiadas ao longo do texto, com o intuito de burla de competência jurisdicional; iii)

da colaboração em outros processos. Tais necessidades são reconhecidas também pelo sistema de justiça penal negociada do Brasil.

${ }^{111}$ Nessa linha: Strang, (2014, p. 33) e Thaman, (2019, p. 3). Contudo, este último autor lista alguns Estados em que excepcionalmente os tribunais obrigam os promotores a aceitar os acordos feitos entre polícia e investigado, exemplificando com o caso People v. Stapinski, julgado pela Suprema Corte do Estado de Illinois em 2015. 
embora a Lei 13.964/2019 tenha trazido reais mudanças, permanece a indefinição sistêmica, viabilizando o surgimento da inusitada figura do "juiz camaleão", o qual atua concomitantemente com características inquisitoriais e adversariais, evidenciado um perigoso sistema híbrido; iv) os problemas gerados pela dupla análise judicial do acordo de colaboração premiada são potencializados nesse sistema híbrido, o qual possibilita a variabilidade do standard probatório aceitável para homologação daqueles acordos, impedindo a identificação de um padrão de atuação judicial; v) nesse ambiente, os conceitos de verdade, o peso da confissão e a gestão da prova assumem natureza ambivalente, gerando insegurança jurídica; vi) por fim, ante as razões já delineadas e na esteira do direito comparatístico, a Lei 12.850/2013 deve ser alvo de mudança, prevendo a supervisão judicial do acordo de colaboração premiada somente ao fim de cada processo correlato, após esgotamento da atividade do colaborador, medida essa que simplificaria o rito, reduziria as chances de nulidades e, ao menos tempo, potencializaria o combate às organizações criminosas e à corrupção sistêmica, sem ferir garantias fundamentais dos colaboradores.

Nesse confuso panorama, o juiz deve atuar buscando sempre preservar o devido processo penal como ponto de equilíbrio do sistema, aguardando uma definição que pode ocorrer via modificação legislativa (conforme proposto) ou mesmo pela consolidação do sistema vigente, fruto de possível tradução realizada pelos atores processuais brasileiros. Caminhando pela seara da imparcialidade e sem ser molestado pelo vírus do utilitarismo, o juiz deve pautar sua atuação mirando a Constituição e todo o catálogo de garantias ali previstos, contribuindo assim para inocorrência de nulidades processuais, viabilizando a análise meritória e definitiva dos processos. Deve manter-se longe do populismo dos últimos tempos e abraçar as cores da razão até que o sistema processual penal de barganha brasileiro ganhe uma padronização capaz de traduzir mais eficiência e segurança jurídica.

\section{REFERÊNCIAS}

AMBOS, Kai. International criminal procedure: "adversarial”, "inquisitorial” or mixed? International criminal Law Review, [s. l.], n. 3, p. 1-37, 2003. 
BADARÓ, Gustavo Henrique. A conexão no processo penal, segundo o princípio do juiz natural, e sua aplicação nos processos da Operação Lava. Revista Brasileira de Ciências Criminais, São Paulo, v. 122, p. 171-204, ago. 2016.

BADARÓ, Gustavo Henrique. A colaboração premiada: meio de prova, meio de obtenção de prova ou um novo modelo de justiça penal não epistêmica? In: BOTTINI, Pierpaolo Cruz; MOURA, Maria Thereza de Assis (coord.). Colaboração premiada. São Paulo: Revista dos Tribunais, 2017, p. 127-147.

BADARÓ, Gustavo Henrique. Processo penal. 3. ed. São Paulo: Revista dos Tribunais, 2015.

BOTTINI, Pierpaolo Cruz. A homologação e a sentença na colaboração premiada na ótica do STF. In: BOTTINI, Pierpaolo Cruz; MOURA, Maria Thereza de Assis (coord.). Colaboração premiada. São Paulo: Revista dos Tribunais, 2017, p. 185-200.

BRANDÃO, Nuno. Acordos sobre a sentença penal: problemas e vias de solução. Revista Julgar, Lisboa, n. 25, p. 161-178, 2015.

CANOTILHO, J. J. Gomes; BRANDÃO, Nuno. Colaboração premiada: reflexões críticas sobre os acordos fundantes da Operação Lava Jato. Revista Brasileira de Ciências Criminais, São Paulo, n. 133, p.133-171, jul. 2017.

CHASE, Oscar G. Law, culture and ritual: Disputing systems in cross-cultural context. New York and London: New York University Press, 2005.

DAMASKA, Mirjan R. Il diritto delle prove alla deriva. Trad. di Francesca Cuomo Ulloa (capp. IV, V, VI) e Valentina Riva (Prefazione, Introduzione, capp. I, II e III). Bolonha: Il mulino, 2003.

DAMASKA, Mirjan R. Negotiated justice in international criminal courts. In: THAMAN, Stephen C. (org.). World Plea Bargaining: consensual procedures and the avoidance of the full criminal trial. Durham: Carolina Academic Press, 2010. p. 81-116.

DAMASKA, Mirjan R. The faces of justice and state authority: a comparative approach to the legal process. New Haven: Yale University Press, 1986.

DAMASKA, Mirjan R. The Uncertain Fate of Evidentiary Transplants: Anglo-American and Continental Experiments (1997). Faculty Scholarship Series, [s. l.], n. 1576 , p. 839-852, 1997.

D’AMBROSIO, Loris. Testimoni e collaboratori di giustizia. Padova: Cedam, 2002. 
DE PASCALIS, Paola. Il problema della disciplina del verbale illustrativo in rapporto alla figura dei testimoni di giustizia (art. 16-quarter d.l. 15 gennaio 1991, n. 8). Riv. it. dir. e proc. pen., Milano, fasc. 4, p. 1-23, 2004.

DELMAS-MARTY, Mireille. Reflections on the 'hybridisation' of criminal procedure. Crime, procedure and evidence in a comparative and international context: essay in honour of Professor Mirjan Damaska, Edited by John Jackson, Máximo Langer and Peter Tillers. Oxford and Portland, Oregon: Hart Publishing, 2008.

DIDIER JR., Fredie; BOMFIM, Daniela. Colaboração premiada (Lei n. 12.850/2013): natureza jurídica e controle da validade por demanda autônoma - um diálogo com o Direito Processual Civil. Civil Procedure Review, München, v. 7, n. 2, p. 135-189, may.-aug. 2016.

DURKHEIM, Émile. Les régles de la méthode sociologique. Collection: Bibliothèque de Philosophie Contemporaine. 16. ed. Paris: Les Presses Universitaires de France, 1967.

FEINBERG, Joel. Harm to self. Nova York: Oxford, 1986.

FERRAJOLI, Luigi. Diritto e ragione: teoria del garantismo penale. Prefazione di Norberto Bobbio. 10. ed. Bari: Editori Laterza, 2011.

FESTINGER, Leon. A theory of cognitive dissonance. Califórnia: Stanford University Press, 1957.

GIORDANO, P. Il verbale illustrativo a garanzia del rapporto. Guida al diritto, [s. l.], n. 11, 24.3.2001, p. 56, 2001.

KUHN, Thomas S. The structure of scientific revolutions. 2. ed. Chicago: The University of Chicago Press, 1974.

LANGER, Maximo. From legal transplants to legal translations: the globalization of plea bargaining and the Americanization thesis in criminal procedure. Havard International Law, [s. l.], v. 45, n. 1, p. 1-64, winter. 2004.

LAUDATI, A. La collaborazione con la giustizia ed il verbale illustrativo dei contenuti: Un "oggetto misterioso" introdotto dalla legge 45/2001. Diritto e giustizia, Milano, n. 10, p. 1-34, 2003.

MENDES, Paulo de Sousa. A colaboração premiada à luz do direito comparado. 2018. Texto escrito para Conferência proferida em 02.10.2018, na Escola Alemã de Ciências Criminais (EACC), organizada pelo Centro de Estudos de Direito Penal e Processual Penal Latino-americano (CDPAL) e pelo Departamento de Direito Penal Estrangeiro da Universidade de Göttingen, sob a direção do Prof. 
Dr. h.c. Kai Ambos e a Coordenação de Eneas Romero e Diego Reis, em 1-5 de outubro de 2018. 2018a.

MENDES, Paulo de Sousa. Lições de Direito Processual Penal. 5. reimpressão da edição de setembro de 2013, Coimbra: Almedina, 2018b.

MENDES, Paulo de Sousa. Vale a pena um Direito Penal do ambiente? Lisboa: AAFDL, 2000.

MENDONÇA, Andrey Borges de. Os benefícios possíveis na colaboração premiada: entre a legalidade e a autonomia de vontade. In: BOTTINI, Pierpaolo Cruz; MOURA, Maria Thereza de Assis (coord.). Colaboração premiada. São Paulo: Revista dos Tribunais, 2017. p. 53-101.

O'CONNOR, Eoin. Negotiated justice - Ireland, England and Wales: plea-bargaining, deferred prosecution agreements and immunity from prosecution. 2019. Trabalho apresentado ao Workshop e Conferência Internacional sobre Colaboração Premiada, 15 e 16 de abril de 2019, Lisboa, p. 1-25. No prelo.

OMODEI, Ricardo Ercole. La collaborazione processuale in materia di associazione a delinquere di stampo mafioso: Brevi cenni alla disciplina italiana. Destinatário: Paulo Roberto Fonseca Barbosa. Gottingen, Alemanha, 04 out. 2019. 1 mensagem eletrônica.

ORLANDI, Renzo. “Operazione mani pulite” e seu contexto político, jurídico e constitucional. Constituição, Economia e Desenvolvimento: Revista da Academia Brasileira de Direito Constitucional, Curitiba, v. 8, n. 15, p. 378-405, jul.-dez. 2016.

ORLANDI, Renzo. Dichiarazioni dell'imputato su responsabilità altrui: nuovo statuto del diritto al silenzio e restrizioni in tema d'incompatibilità a testimoniare. Il giusto processo: tra contraddittorio e diritto al silenzio. Roberto E. Kostoris (a cura di). Torino: G. Giappicheli Editore, 2002.

ORLANDI, Renzo. I collaboratori di giustizia nell'esperienza italiana. 2019. Trabalho apresentado ao Workshop e Conferência Internacional sobre Colaboração Premiada, 15 e 16 de abril de 2019, Lisboa, p. 1-14. No prelo.

PALOMARES, Salvador Guerrero. La imparcialidad objetiva del juez penal: análisis jurisprudencial y valoración crítica. Pamplona: Thompson Reuters, 2009.

PANZAVOLTA, Michele. Reforms and counter-reforms in the italian struggle for na accusatorial criminal law system. North Carolina Journal of International Law \& Commercial Regulation, Chapel Hill, v. 30, n. 3, p. 577-624, 2005. 
RIVA, Carlo Ruga. Il premio per la collaborazione processuale. Milano: Dott. A. Giuffrè Edittore, 2002.

ROMERO, Eneas. A colaboração premiada. In: AMBOS, Kai; ROMERO, Eneas (coord.). Crime organizado: análise da Lei n. ${ }^{0}$ 12.850/2013. São Paulo: Marcial Pons; CDPAL, 2017, p. 253-278.

ROTH, Jéssica A. Informant witness and the risk of wrongful convictions. American Criminal Law Review, New York, n. 737, p. 737-797, 2016.

RUGGIERO, Rosa Anna. Speciale programma di protezione e affidabilità del “pentito”. Cass. pen., Milano, fasc. 7-8, p. 2512B, p. 1-6, 2010.

SANNA, Alessandra. Il "patteggiamento" tra prassi e novelle legislative: questioni nuove di procedura penale. Padova: CEDAM, 2018.

SCHABAS, William A. An introduction to the International Criminal Court. Fifth edition. Cambridge: Cambridge University Press, 2018.

SCHÜNEMANN, Bernd. Do templo ao mercado? Como a justiça penal aparentemente transforma a teoria econômica do direito em prática, governo em governança e soberania em cooperação. In: GRECO, Luís (coord.). Estudos de direito penal, direito processual penal e filosofia do direito. São Paulo: Marcial Pons, 2013a, p. 298-326.

SCHÜNEMANN, Bernd. O juiz como um terceiro manipulado no processo penal? Uma confirmação empírica dos efeitos perseverança e correspondência comportamental. In: GRECO, Luís (coord.). Estudos de direito penal, direito processual penal e filosofia do direito. São Paulo: Marcial Pons, 2013b, p. 205-221.

STRANG, Robert R. Plea bargaining, cooperation agreements, and immunity orders. In: INTERNATIONAL TRANING COURSE VISITINGS EXPERT'S PAPERS, 155., 2015, Japão. Anais [...]. Japão: UNAFEI, 2014. p. 30-37. (Resource material series, n. 92). Disponível em: <https://pdfs.semanticscholar.org/04ee/8da129e50f2cf4f8ce3cdc4df46bc3cabfa3.pdf?_ga=2.211568535.364331692.1552851463661853801.1552851463>. Acesso em: 05 jun. 2019.

THAMAN, Stephen C. Cooperation agreements in U.S. criminal law: do they enhance truth in factfinding in serious case? 2019. Trabalho apresentado ao Workshop e Conferência Internacional sobre Colaboração Premiada, 15 e 16 de abril de 2019, Lisboa, p. 1-16. No prelo.

TONINI, Paolo. Manuale di Procedura Penale. Diciannovesima edizione. Milano: Giuffrè Editore, 2018. 
TURNER, Jenia Iontcheva. Judicial participation in plea negotiation: a comparative view. The American Journal of Comparative Law, Berkeley, v. 54, p. 501-570, 2006. VASCONCELLOS, Vinicius Gomes de. Colaboração premiada no processo penal. 2. ed. rev., atual. e ampl. São Paulo: Thompson Reuters Brasil, 2018.

VERÍSSIMO, Carla. Principais questões sobre a competência para a homologação do acordo de colaboração premiada. In: BOTTINI, Pierpaolo Cruz; MOURA, Maria Thereza de Assis (coord.). Colaboração premiada. São Paulo: Revista dos Tribunais, 2017, p. 111-126.

WATANABE, Kazuo. Da cognição no processo civil. São Paulo: Perfil, 2005.

WATSON, Alan. Legal Transplants: An Approach to Comparative Law. Second edition. Athens-London: The University of Georgia Press, 1993.

WEIGEND, Thomas. The decay of the inquisitorial ideal: plea bargaining invades german criminal procedure. Crime, procedure and evidence in a comparative and international context: essay in honour of Professor Mirjan Damaska. Edited by John Jackson, Máximo Langer and Peter Tillers. Oxford and Portland, Oregon: Hart Publishing, 2008.

ZILLI, Marcos. No acordo de colaboração entre gregos e troianos o cavalo é o prêmio. Boletim IBCCrim, São Paulo, ano 25, n. 300, p. 3-6, novembro, 2017.

ZILLI, Marcos. Pactum virae. O acordo de colaboração premiada no processo penal brasileiro. Liberdade de negociação e controle judicial. Complexo de Jano? 2019. Trabalho apresentado ao Workshop e Conferência Internacional sobre Colaboração Premiada, 15 e 16 de abril de 2019, Lisboa, 2019a, p. 1-31. No prelo.

ZILLI, Marcos. Transplantes, traduções e cavalos de troia. O papel do juiz no acordo de colaboração premiada. Leituras à luz da operação lava jato. In: AMBOS, Kai; ZILLI, Marcos; MENDES, Paulo de Sousa (coord.). Corrupção: ensaios sobre a operação lava jato. São Paulo: Marcial Pons; CDPAL, 2019b, p. 93-132. 


\section{Informações adicionais e declarações dos autores (integridade científica)}

Agradecimentos (acknowledgement): Agradeço ao Professor Riccardo Omodei pela acolhida na cidade de Palermo e por sua gentileza em me conceder elucidativa entrevista sobre o funcionamento do "verbale illustrativo dei contenuti della collaborazione", entregando-me, inclusive, via e-mail, texto de sua autoria ainda pendente de publicação.

Declaração de conflito de interesses (conflict of interest declaration): o autor confirma que não há conflitos de interesse na realização das pesquisas expostas e na redação deste artigo.

Declaração de autoria e especificação das contribuições (declaration of authorship): todas e somente as pessoas que atendem os requisitos de autoria deste artigo estão listadas como autores; todos os coautores se responsabilizam integralmente por este trabalho em sua totalidade.

Declaração de ineditismo e originalidade (declaration of originality): o autor assegura que o texto aqui publicado não foi divulgado anteriormente em outro meio e que futura republicação somente se realizará com a indicação expressa da referência desta publicação original; também atesta que não há plágio de terceiros ou autoplágio. 


\section{Dados do processo editorial}

(http://www.ibraspp.com.br/revista/index.php/RBDPP/about/editorialPolicies)

- Recebido em: 23/05/2020

- Controle preliminar e verificação de plágio: 27/06/2020

- Avaliação 1: 08/07/2020

- Avaliação 2: 15/07/2020

- Avaliação 3: 20/07/2020

- Decisão editorial preliminar: 23/08/2020

- Retorno rodada de correções: 05/09/2020

- Decisão editorial final: 21/09/2020

\section{Equipe editorial envolvida}

- Editor-chefe: 1 (VGV)

- Editor-associado: 1 (RO)

- Revisores: 3

\section{COMO CITAR ESTE ARTIGO:}

BARBOSA, Paulo Roberto Fonseca. Colaboração premiada, paternalismo processual e "juízes camaleões": simplificação e eficiência do procedimento na luta contra a corrupção. Revista Brasileira de Direito Processual Penal, Porto Alegre, vol. 6, n. 3, p. 1301-1344, set./dez. 2020.

https://doi.org/10.22197/rbdpp.v6i3.393

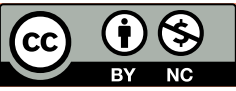

Esta obra está licenciada com uma Licença Creative Commons Atribuição-NãoComercial 4.0 Internacional. 